\title{
Association among Vitamin D, Retinoic Acid-Related Orphan Receptors, and Vitamin D Hydroxyderivatives in Ovarian Cancer
}

\author{
Anna A. Brożyna ${ }^{1, *}$, , Tae-Kang Kim ${ }^{2}\left(\mathbb{D}\right.$, Marzena Zabłocka ${ }^{3}$, Wojciech Jóźwicki ${ }^{4}$, \\ Junming Yue ${ }^{5}$, Robert C. Tuckey ${ }^{6}{ }^{D}$, Anton M. Jetten ${ }^{7}$ and Andrzej T. Slominski ${ }^{2,8, *(D)}$ \\ 1 Department of Human Biology, Institute of Biology, Faculty of Biological and Veterinary Sciences, \\ Nicolaus Copernicus University, 87-100 Toruń, Poland \\ 2 Department of Dermatology, University of Alabama at Birmingham, Birmingham, AL 35294, USA; \\ tkim@uabmc.edu \\ 3 Department of Tumor Pathology and Pathomorphology, Oncology Centre-Prof. Franciszek Łukaszczyk \\ Memorial Hospital in Bydgoszcz, 85-796 Bydgoszcz, Poland; marzenazablocka_73@wp.pl \\ 4 Department of Tumor Pathology and Pathomorphology, Department of Oncology, \\ Faculty of Health Sciences, Ludwik Rydygier Collegium Medicum in Bydgoszcz, \\ Nicolaus Copernicus University, 87-100 Torun, Poland; jozwickiw@cm.umk.pl \\ 5 Department of Pathology, University of Tennessee Health Science Center, Memphis, TN 38163, USA; \\ jyue@uthsc.edu \\ 6 School of Molecular Sciences, The University of Western Australia, Perth, WA 6009, Australia; \\ robert.tuckey@uwa.edu.au \\ 7 Cell Biology Section, Immunity, Inflammation and Disease Laboratory, National Institute of Environmental \\ Health Sciences, National Institutes of Health, Research Triangle Park, NC 27709, USA; jetten@niehs.nih.gov \\ 8 Laboratory Service of the VA Medical Center, Birmingham, AL 35294, USA \\ * Correspondence: anna.brozyna@umk.pl (A.A.B.); aslominski@uabmc.edu (A.T.S.); \\ Tel.: +4856-611-4599 (A.A.B.); +205-934-5245 (A.T.S.); Fax: +4856-611-4772 (A.A.B.); +205-996-0302 (A.T.S.)
}

Received: 15 October 2020; Accepted: 12 November 2020; Published: 19 November 2020

\begin{abstract}
Vitamin D and its derivatives, acting via the vitamin D receptor (VDR) and retinoic acid-related orphan receptors $\gamma$ and $\alpha(\operatorname{ROR} \gamma$ and $\operatorname{ROR} \alpha)$, show anticancer properties. Since pathological conditions are characterized by disturbances in the expression of these receptors, in this study, we investigated their expression in ovarian cancers (OCs), as well as explored the phenotypic effects of vitamin D hydroxyderivatives and ROR $\gamma / \alpha$ agonists on OC cells. The VDR and ROR $\gamma$ showed both a nuclear and a cytoplasmic location, and their expression levels were found to be reduced in the primary and metastatic OCs in comparison to normal ovarian epithelium, as well as correlated to the tumor grade. This reduction in VDR and ROR $\gamma$ expression correlated with a shorter overall disease-free survival. VDR, ROR $\gamma$, and ROR $\alpha$ were also detected in SKOV-3 and OVCAR-3 cell lines with increased expression in the latter line. 20-Hydroxy-lumisterol3 $\left(20(\mathrm{OH}) \mathrm{L}_{3}\right)$ and synthetic $\mathrm{ROR} \alpha / \mathrm{ROR} \gamma$ agonist $\mathrm{SR} 1078$ inhibited proliferation only in the OVCAR-3 line, while 20-hydroxyvitamin- $\mathrm{D}_{3}\left(20(\mathrm{OH}) \mathrm{D}_{3}\right)$ only inhibited SKOV-3 cell proliferation. $1,25(\mathrm{OH})_{2} \mathrm{D}_{3}$, $20(\mathrm{OH}) \mathrm{L}_{3}$, and SR1078, but not $20(\mathrm{OH}) \mathrm{D}_{3}$, inhibited spheroid formation in SKOV-3 cells. In summary, decreases in VDR, ROR $\gamma$, and ROR $\alpha$ expression correlated with an unfavorable outcome for OC, and compounds targeting these receptors had a context-dependent anti-tumor activity in vitro. We conclude that VDR and ROR $\gamma$ expression can be used in the diagnosis and prognosis of OC and suggest their ligands as potential candidates for OC therapy.
\end{abstract}

Keywords: ovarian cancers; vitamin D; nuclear receptors; VDR; ROR $\alpha$; ROR $\gamma$ 


\section{Introduction}

Ovarian cancer (OC) is the seventh most frequent cancer in women and the leading cause of death in patients with gynecological cancer, with a higher incidence rate and poorer prognosis in less developed counties [1,2]. Since early OC is mostly asymptomatic, most cases $(75 \%)$ are diagnosed at advanced stages [3]. The 5 year relative survival rate for invasive epithelial ovarian cancer patients is about $45 \%$ for all stages $[1,2]$. OC risk factors include older age, obesity, late pregnancy or nulliparity, in vitro fertilization, hormone replacement therapy based on estrogen alone, and genetic predisposition (for example, mutations in BRCA1, BRCA2, PTEN, LH1, MLH3, MSH2, MSH6, TGFBR2, PMS1, PMS2, STK11, MUTYH, and other genes [1]). At an early stage, OC is sensitive to current treatment regimens (5 year relative survival rate for stage I is $90 \%$ ). Despite the improvement in treatment, OC patients develop recurrent disease very often, with an overall recurrence rate of $75 \%$, up to $10-30 \%$ at early stages [3-5]. Although the 5 year relative survival rate has slightly improved, especially for Caucasians, high recurrence and mortality rates indicate the clear need for developing new methods for early diagnosis, recurrence prediction, and an efficient adjuvant treatment of OC.

It is widely appreciated that active forms of vitamin D can act as anticancer agents, inhibiting proliferation, stimulating differentiation and apoptosis, affecting tumor microenvironment, and modulating the immune response and sensitivity to antitumor therapies [6-22]. Vitamin D is formed in the skin after absorption of the ultraviolet B (UVB) energy by 7-dehydrocholesterol or is acquired via a food supplement [23-31]. In the canonical pathway, it is activated by two separate hydroxylation steps. The first step takes place in the liver and is catalyzed by 25-hydroxylases, cytochrome P450 (CYP)27A1 and CYP2R1, followed by the second hydroxylation at C1 $\alpha$ in the kidneys catalyzed by CYP27B1, generating the hormonally active $1,25(\mathrm{OH})_{2} \mathrm{D}_{3}[17,32,33]$. In recently discovered noncanonical pathways of activation, vitamin D3 or lumisterol is hydroxylated at C20 to produce 20-hydroxyvitamin $\mathrm{D} 3(20(\mathrm{OH}) \mathrm{D} 3)$ or 20-hydroxylumisterol $\left(20(\mathrm{OH}) \mathrm{L}_{3}\right)$ as biologically active intermediates [34-37].

Epidemiological studies indicate that low vitamin D serum levels are related to higher OC risk and poorer prognosis [38,39]. Furthermore, decreased CYP27B1 expression in cancer cells is related to a poorer clinical outcome [40]. Active forms of vitamin D express anticancer properties via interaction with the vitamin $\mathrm{D}$ receptor (VDR) which is present in a variety of normal and cancerous tissues $[17,18,41]$. After binding $1,25(\mathrm{OH})_{2} \mathrm{D}_{3}$, the VDR heterodimerizes with retinoid $\mathrm{X}$ receptor (RXR) and translocates to the nucleus where the heterodimeric complex binds to vitamin $\mathrm{D}$ response elements (VDREs) to regulate the transcription of target genes [42-46]. Recently, retinoic acid-related orphan receptors (RORs) $\alpha$ and $\gamma$ were shown to function as receptors for several vitamin D hydroxyderivatives $[47,48]$. RORs are involved in diverse cellular functions, including metabolism, immunity, and differentiation development [49-51]. Previously, we reported that ROR $\alpha$ and ROR $\gamma$ are expressed in normal human skin and melanomas and that their expression decreases during the progression of melanocytic tumors [48,52]. The expression of these receptors correlated with intramural expression of HIF-1 $\alpha$ (hypoxia-inducible factor 1 alpha) [53]. In addition, the reduced expression of ROR $\gamma$ was related to poorer melanoma prognosis [52].

In this study, we tested whether VDR, ROR $\gamma$, and ROR $\alpha$ are expressed in ovarian cancers, and we correlated their expression with clinico-pathological data, including patient survival time. Moreover, we investigated the effects of hydroxyderivatives of vitamin D and lumisterol, as well as ROR $\gamma / \alpha$ agonists, on ovarian cancer cells cultured in vitro. 


\section{Materials and Methods}

\subsection{Clinico-Pathological Studies}

\subsubsection{Patients}

The ovarian cancer patients of the Oncology Center in Bydgoszcz, Poland treated between December 2006 and January 2010 were chosen consecutively from a patient digital database on the basis of pathomorphological diagnosis. After evaluation of quality and availability of histological material, 103 tissue blocks (including 65 ovarian tumors, 16 metastases, and 22 normal ovaries) from 68 patients were included in this study. The study was approved by the Institutional Review Board of Collegium Medicum, Nicolaus Copernicus University (KB446/2009 and KB344/2014) and adhered to the tenets of the Declaration of Helsinki. The clinico-pathomorphological characteristics of the patients included in this study are presented in Table 1.

Table 1. Pathomorphological characteristic of the patients included in the present study.

\begin{tabular}{cc}
\hline Feature & Number of Cases \\
\hline Age & Mean 55.8 years (25.6-84.3) \\
<40 years & 3 \\
$41-50$ years & 14 \\
$51-60$ years & 36 \\
61-70 years & 10 \\
>70 years & 5 \\
Grading * & \\
G1 & 3 \\
G2 & 19 \\
G3 & 43 \\
Grading ** & \\
G1 & 0 \\
G2 & 9 \\
G3 & 7 \\
Histological type * & \\
Borderline & 2 \\
Serous adenocarcinoma & 50 \\
Clear-cell carcinoma & 3 \\
Endometrioid cancer & 6 \\
Mucinous cancer & 1 \\
Transitional cell carcinoma & 1 \\
Other & 2 \\
Necrosis * & \\
Absent & \\
Present & \\
Metastases ${ }^{*}$ & \\
Absent & \\
Present & \\
\hline metastatic tumors; ${ }^{*}$ metastases present at the time of cytoreductive surgery. &
\end{tabular}

\subsubsection{Immunohistochemistry}

The expression of $\operatorname{ROR} \gamma, \operatorname{VDR}$ and $\operatorname{ROR} \alpha$ in ovarian tissues was analyzed by immune histochemistry, as described previously [52,54-56]. Briefly, after antigen retrieval, formalin-fixed, paraffin-embedded $4 \mu \mathrm{m}$ sections were incubated with primary antibodies anti-ROR $\gamma$ (generated as previously described [48,57]), anti-VDR (clone 9A7, Millipore, Merck KGaA, Darmstadt, Germany), or anti-ROR $\alpha$ (generated as previously described $[48,57]$ ) overnight at $4{ }^{\circ} \mathrm{C}$. For the detection of ROR $\gamma$ and $\alpha$, after extensive washing, the sections were incubated with secondary antibody EnVision ${ }^{\mathrm{TM}}$ FLEX/HRP (Dako, Carpinteria, CA, USA) and visualized with Vector NovaRED (Vector Laboratories Inc., Burlingame, CA, USA), before being counterstained with hematoxylin, dehydrated, and mounted in 
permanent medium (Consul Mount; Thermo Fisher Scientific Inc. Waltham, MA, USA). For the detection of VDR, after extensive washing, slides were incubated with anti-rat secondary antibody conjugated to HRP (Jackson ImmunoResearch Europe Ltd., Ely, UK), then visualized with ImmPACT NovaRED (Vector Laboratories Inc., Burlingame, CA, USA), and mounted in permanent medium (Consul Mount; Thermo Fisher Scientific Inc. Waltham, MA, USA). For each run of immunohistochemistry, negative and positive controls were prepared. In negative controls, primary antibody was omitted. Kidney samples served as positive controls for ROR $\gamma$ and VDR, and skin samples served as positive controls for ROR $\alpha$. Slides were analyzed using a Nikon Eclipse 80i light microscope (equipped with Nikon Digital Sight DS Fi1-U2 digital camera and NIS-Elements BR 3.0 software (Nikon Instruments Europe BV, Badhoevedorp, the Netherlands). The expression of CYP27B1 and RCAS1 (receptor binding cancer antigen expressed on SiSo cells) was detected using immunohistochemistry, as previously described $[56,58,59]$.

\subsubsection{Immunohistochemistry Assessments}

Clinical data, histopathological diagnosis, and other relevant data were blinded during immunohistochemical evaluation of immunostained sections. The immunostaining was analyzed semiquantitatively, with both percentage and immunostaining intensity evaluation. The semiquantitative score (SQ-score) was calculated as follows: $\mathrm{SQ}=$ mean $(\mathrm{IR} \times \mathrm{SI})$, where IR is the percentage of immunopositive cells and SI is the staining intensity (assessed using the scale from 0 to 3 arbitrary units (AU). Since mean nuclear ROR $\gamma$ immunostaining was stronger than cytoplasmic staining, we applied different cut-off SQ-scores for those compartments. According to cytoplasmic ROR $\gamma$ SQ-score, patients were stratified as follows: SQ 0.0-50.0 = ROR $\gamma$ absent, SQ 50.1-75.00 = low ROR $\gamma$, and SQ 75.1-300.0 $=$ high ROR $\gamma$. According to nuclear ROR $\gamma$ SQ-score patients were stratified as follows: SQ 0.0-75.0 = ROR $\gamma$ absent, SQ 75.1-100.0 = low ROR $\gamma$, and SQ 100.1-300.0 = high ROR $\gamma$. VDR-stained ovarian sections were stratified according to SQ-score as follows: SQ 0.0-69.99= VDR absent, SQ 70.00-300.00 = VDR present for nuclear VDR, and SQ 0.0-50.00 = VDR absent, SQ $50.1-300.00=$ VDR present for cytoplasmic VDR. Immunohistochemical evaluations of CYP27B1 and RCAS1 expression were performed using immunohistochemistry, as previously described $[58,60]$. Since the availability of the tumor tissue in the many OCs blocks was exhausted, clinico-pathologic correlation for ROR $\alpha$ was not performed, and only descriptive data were presented.

\subsection{Cell Culture-Based Studies}

\subsubsection{Cell Culture and Treatment}

The human ovarian epithelial adenocarcinoma cell lines SKOV-3 and OVCAR-3 were from the American Type Culture Collection (ATCC). The SKOV-3 cell line was cultured in Roswell Park Memorial Institute (RPMI) medium 1640 containing L-glutamine (Cellgro, Manassas, VA, USA). The OVCAR-3 cell line was maintained in Dulbecco's modified Eagle's medium (DMEM) medium (Cellgro, Manassas, VA, USA). Both media were supplemented with 10\% fetal bovine serum (FBS; Atlanta Biologicals, Inc, Flowery Branch, GA, USA) and 1\% antibiotic-antimycotic solution (Mediatech, Inc. Manassas, VA, USA). All cells were cultured in a humidified atmosphere with $5 \% \mathrm{CO}_{2}$ at $37^{\circ} \mathrm{C}$.

Cells were treated with 1,25-dihydroxyvitamin- $\mathrm{D}_{3}\left(1,25(\mathrm{OH})_{2} \mathrm{D}_{3}\right)$ (Sigma-Aldrich, St. Louis, MO, USA), 20-hydroxyvitamin-D3 $\left(20(\mathrm{OH}) \mathrm{D}_{3}\right)$, 20-hydroxy-lumisterol $3\left(20(\mathrm{OH}) \mathrm{L}_{3}\right)$, and the synthetic $\mathrm{ROR} \alpha / \mathrm{ROR} \gamma$ agonist, SR1078 (Sigma-Aldrich, St. Louis, MO, USA). $20(\mathrm{OH}) \mathrm{D}_{3}$ was enzymatically synthesized with a reconstituted CYP11A1-mediated system using vitamin D3 from Sigma-Aldrich (St. Louis, MO, USA) as the substrate [61,62]. 20(OH) $\mathrm{L}_{3}$ was a product of photochemical transformation of 20-hydroxy-7-dehydrocholestrol as described previously [63]. The products were purified by thin-layer chromatography, followed by reversed-phase high-performance liquid chromatography. Their molecular identities were confirmed by mass and UV spectra and NMR as described previously [62,63], and they were stored until use at $-80{ }^{\circ} \mathrm{C}$. All compounds being tested were dissolved in $100 \%$ ethanol. Control cells were treated with $0.1 \%$ ethanol, corresponding to the concentration of the ethanol in the treatment 
with $10^{-6} \mathrm{M} 1,25(\mathrm{OH})_{2} \mathrm{D}_{3}$ or SR1078, or $10^{-7} \mathrm{M} 20(\mathrm{OH}) \mathrm{D}_{3}$ or $20(\mathrm{OH}) \mathrm{L}_{3}$. During treatment, $5 \%$ charcoal/dextran-treated bovine serum (Atlanta Biologicals, Inc, Flowery Branch, GA, USA) was used.

\subsubsection{Fluorescent Immunocytochemistry (F-ICC)}

Cells were seeded in a 96-well plate and grown until reaching $~ 70 \%$ confluence. Then, cells were fixed with $4 \%$ buffered formalin for $20 \mathrm{~min}$ at room temperature (RT), followed by permeabilization and blocking with $0.5 \%$ Triton X-100 and $2 \%$ bovine serum albumin (BSA) in phosphate-buffered saline (PBS) for $1 \mathrm{~h}$ at RT. Primary rabbit anti-ROR $\gamma$ antibody (developed at National Institute of Environmental Health Sciences (NIEHS, USA) [48,57]) diluted in 1\% BSA solution was applied overnight at $4{ }^{\circ} \mathrm{C}$. After extensive washing in PBS, the secondary antibody (goat anti-rabbit immunoglobulin G (IgG) $(\mathrm{H}+\mathrm{L})$ Cross-Adsorbed Secondary Antibody, Alexa Fluor 488, A-11008, Thermo Fisher Scientific, Inc., Waltham, MA, USA), diluted 1:1000 in 1\% BSA solution was applied for $1 \mathrm{~h}$ at RT. Then, nuclei of cells were stained with propidium iodide (PI) (Sigma, Saint Louis, MO, USA) and examined with a Cytation 5 microplate reader, equipped with appropriate filters capable of visualization of green and blue fluorophores and Gene5 software (BioTek, Winooski, VT, USA). The positive control consisted of $\mathrm{HaCaT}$ cells. In the negative control, the primary antibody was omitted.

\subsubsection{Western Blot (WB)}

OVCAR-3 and SKOV-3 cells were grown as described above, and protein extraction was performed as described previously [64]. Briefly, the cell extract was obtained by dissolving cell pellets in radioimmunoprecipitation assay (RIPA) buffer and incubating on ice for $10 \mathrm{~min}$ followed by centrifugation at $15,000 \times g$ for $10 \mathrm{~min}$. The nuclear and cytoplasmic fractions were isolated separately with a Nuclear Extract Kit (Active Motif, Inc., Carlsbad, CA, USA) following the manufacturer's protocol. Briefly, cells were suspended in hypotonic buffer and vortexed after adding detergent followed by centrifugation at $14,000 \times g$ for $30 \mathrm{~s}$. The supernatant was used as the cytoplasmic fraction, and the pellet was resuspended in lysis buffer followed by incubating on ice for $30 \mathrm{~min}$. The samples were centrifuged for $10 \mathrm{~min}$ at $14,000 \times g$, and the supernatant was used as the nuclear fraction. Protein concentration was determined using a bicinchoninic acid (BCA) Protein Assay kit (Thermo Fisher Scientific, Waltham, MA, USA). Fifty micrograms of extracted protein was subjected to SDS/PAGE using a 4-15\% acrylamide gel (Bio-Rad Laboratories, Inc., Hercules, CA, USA). Western blots were performed as described previously $[41,52,64]$. Briefly, after transfer of the proteins to a polyvinylidene fluoride (PVDF) membrane (Millipore Sigma, Burlington, MA, USA), the membrane was blocked with $5 \%$ nonfat dry milk followed by incubation with primary antibodies at a dilution of 1:200 for anti-VDR monoclonal antibody (D-6) (Santa Cruz Biotechnology, Dallas, TX, USA), 1:1000 for anti-ROR $\alpha$ polyclonal antibody (Invitrogen, Waltham, MA, USA), or 1:500 for anti-ROR $\gamma(\mathrm{t})$ monoclonal antibody (Invitrogen, Waltham, MA, USA). As secondary antibodies, 1:4000 diluted anti-mouse IgG kappa binding protein conjugated to horseradish peroxidase (HRP) (Santa Cruz Biotechnology, Dallas, TX, USA) was used for VDR, while 1:5000 diluted goat anti-rabbit IgG (Abcam, Cambridge, MA, USA) or 1:2000 diluted anti-rat IgG HRP-linked antibody (Cell signaling Technology, Danvers, MA, USA) was used for ROR $\alpha$ or ROR $\gamma$, respectively.

\subsubsection{Cell Proliferation Assay}

Cells were seeded in 96-well plates (TPP, Trasadingen, Switzerland) and grown until reaching $\sim 70 \%$ confluence. Then, OVCAR-3 cells were serum-starved for $24 \mathrm{~h}$, followed by treatment with the abovementioned compounds for 24 or $48 \mathrm{~h}$. The starvation step was omitted in experiments using the SKOV-3 cell line. To assess the number of viable cells, the CellTiter 96 AQueous One Solution Cell Proliferation Assay (Promega Corporation, Madison, WI, USA) was used, according to the manufacturer's protocol. Briefly, $20 \mu \mathrm{L}$ of MTS (3-(4,5-dimethylthiazol-2-yl)-5-(3-carboxymethoxyphenyl)-2-(4-sulfophenyl)-2H-tetrazolium, inner salt) was added to each well, and plates were incubated for $2 \mathrm{~h}(\mathrm{SKOV}-3)$ or $3 \mathrm{~h}$ (OVCAR-3) at $37^{\circ} \mathrm{C}$, 
followed by reading the absorbance at $490 \mathrm{~nm}$ using a Cytation 5 reader and Gene5 software (BioTek, Winooski, VT, USA). All experiments were performed in triplicate.

\subsubsection{Spheroid Formation}

The spheroid assay was performed according to the protocol of Johnson et al. [65]. Briefly, SKOV-3 cells (400 cells per well) were seeded in RPMI-1640 medium (Cellgro, Manassas, VA, USA), supplemented with $20 \mathrm{ng} / \mathrm{mL}$ epidermal growth factor (Sigma-Aldrich), $10 \mathrm{ng} / \mathrm{mL}$ basic fibroblast growth factor (Sigma-Aldrich), $5 \mu \mathrm{g} / \mathrm{mL}$ insulin (Life Technologies, Invitrogen), $0.4 \%$ bovine serum albumin (Sigma-Aldrich), $1 \times$ B27 supplement (Life Technologies, Invitrogen), and the compounds to be tested, in ultra-low attachment 96-well plates and incubated for 7 days; subsequently, the plates were scanned using a Cytation 5 reader (BioTek, Winooski, VT, USA), and spheroids were counted using Gene5 software (BioTek, Winooski, VT, USA). All experiments were performed in triplicate. OVCAR-3 cells did not form spheroids using the abovementioned protocol.

\subsection{Statistical Analysis}

Prism 5.00 software (GraphPad Software, San Diego, CA, USA) was used for statistical analysis. One-way ANOVA or the $t$-test was used to compare two or more variables. The association between immunostaining and categorical variables was tested using Pearson's correlation. The Kaplan-Meier method was used to analyze the survival data. Results were considered as statistically significant at $p<0.05$.

\section{Results}

\section{1. $R O R \gamma$ Expression in Human Ovarian Tumors Decreases}

ROR $\gamma$ immunostaining was detected predominantly in the nuclei with weaker staining in the cytoplasm (Figure 1A-G. ROR $\gamma$ was found in both normal ovarian epithelial cells and primary and metastatic ovarian tumors; however, in pathological samples, its expression was significantly reduced (Figure 1A,B). For the ovarian cancer patient population included in this study, we analyzed 12 cases of matched pairs of primary and metastatic cancers, but no statistically significant differences were found. ROR $\gamma$ immunostaining decreased with decreasing differentiation levels of tumors. In primary tumors classified according to the cancer grade, there were statistically significant differences in nuclear ROR $\gamma$ levels observed among G1, G2, and G3 tumors (data not shown). Furthermore, those relationships were strongest in cancers classified according tumor grade in analyzed section. A gradual decrease was observed in both cytoplasmic and nuclear ROR $\gamma$ with increasing tumor grade (Figure 1C-F) indicating a strong negative correlation between the tumor grade and receptor expression $(r=-0.35, p=0.0024$ and $r=-0.024, p=0.03$, respectively). In metastatic tumors, we did not observe any relationship between ROR $\gamma$ immunostaining and tumor grade (Figure 1E,F).

Qualitative analysis could only be performed for ROR $\alpha$ because of a limited availability of tumor tissue in paraffin blocks from many patients (Table S1, Supplementary Materials). ROR $\alpha$ expression, similar to ROR $\gamma$, was found predominantly in the nuclei with weaker staining in the cytoplasm (Figure 1G. ROR $\alpha$ staining in ovarian cancers was heterogeneous and ranged from not detectable to strong nuclear and moderate cytoplasmic immunostaining. 

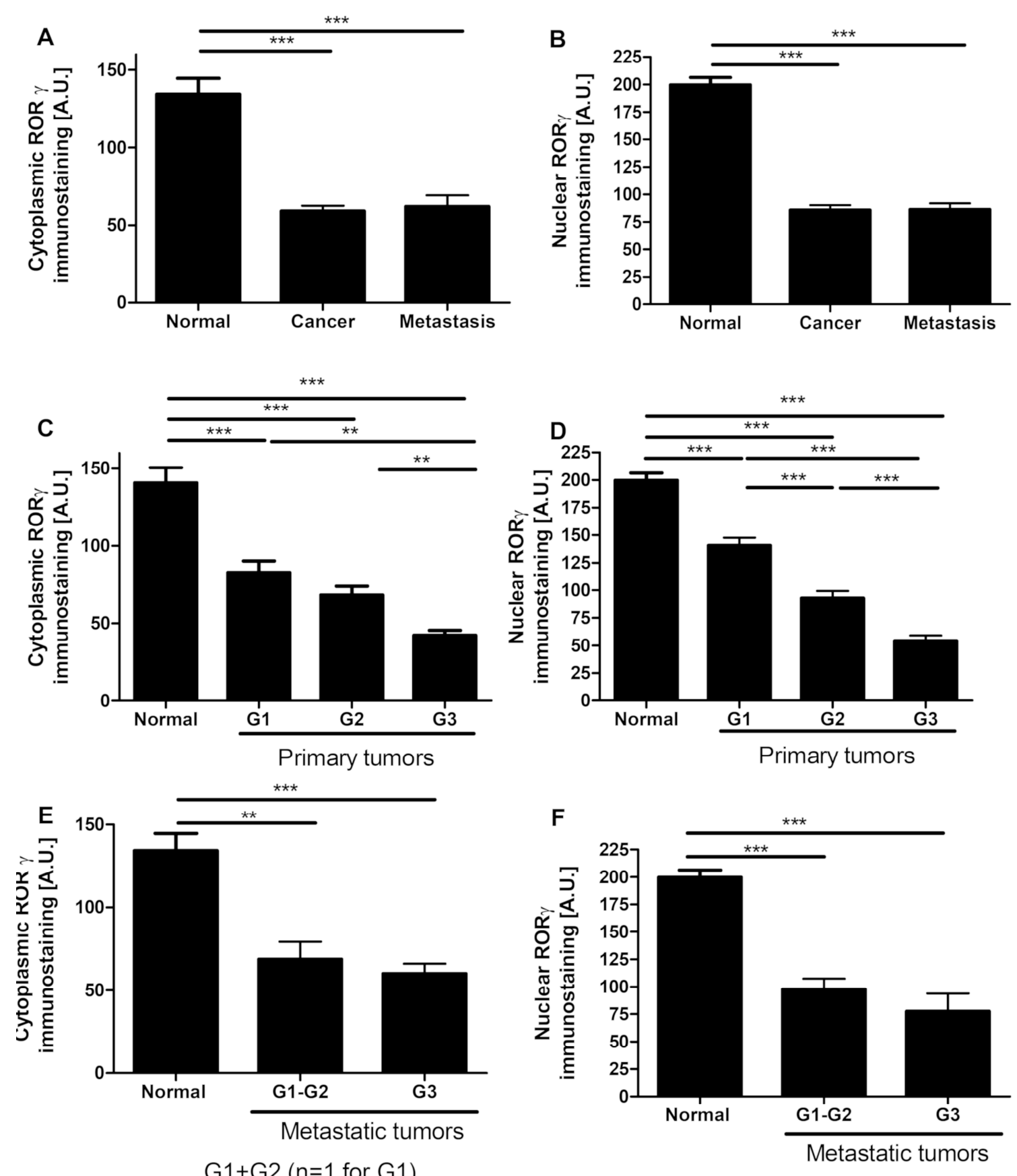

$\mathrm{G} 1+\mathrm{G} 2(\mathrm{n}=1$ for $\mathrm{G} 1)$

$\mathrm{G} 1+\mathrm{G} 2(\mathrm{n}=1$ for $\mathrm{G} 1)$

Figure 1. Cont. 
G
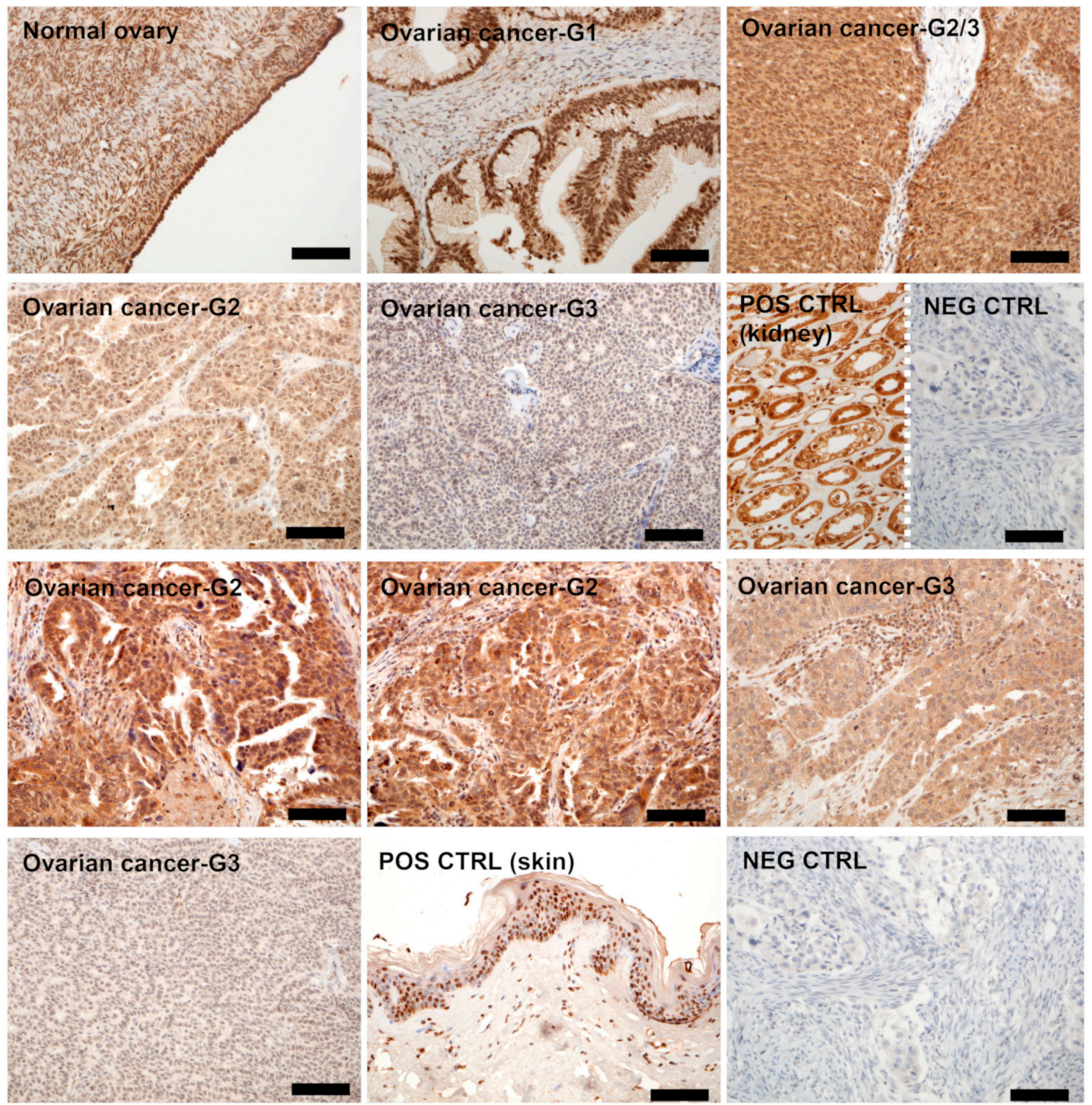

Figure 1. Cytoplasmic and nuclear retinoic acid-related orphan receptor $\gamma$ and $\alpha(\operatorname{ROR} \gamma$ and $\operatorname{ROR} \alpha)$ immunostaining in normal ovary $(n=22)$ and ovarian tumors $(n=65)(\mathbf{A}, \mathbf{B})$, in relation to tumor grade in primary tumors $(\mathbf{C}, \mathbf{D})$ and in metastatic tumors $(n=16)(\mathbf{E}, \mathbf{F})$. Statistically significant differences are denoted with asterisks as determined by ANOVA ( ${ }^{* *} p<0.01$, and ${ }^{* * *} p<0.001$ ). (G) Representative $\mathrm{ROR} \gamma$ immunostaining in normal epithelia, ovarian cancers, and positive (POS CTRL) and negative (NEG CTRL) controls. Scale bars $=50 \mu \mathrm{m}$.

\subsection{ROR $\gamma$ Expression Correlates with CYP27B1 and RCAS1 Expression}

CYP27B1 hydroxylates 25-hydroxyvitamin $\mathrm{D}_{3}$ at position $\mathrm{C} 1 \alpha$ producing biologically active $1,25(\mathrm{OH})_{2} \mathrm{D}_{3}[32,33]$. Since $\mathrm{ROR} \gamma$ can act as receptor for vitamin $\mathrm{D}$, we tested the relationship between CYP27B1 and ROR $\gamma$ expression. A high level of nuclear ROR $\gamma$ immunostaining $(>100$ AU) correlated with high CYP27B1 expression (Figure 2A). No significant relationship was observed between cytoplasmic ROR $\gamma$ and CYP27B1; CYP27B1 expression was the highest in cases with moderate cytoplasmic ROR $\gamma$ immunostaining (50-75 AU) (Figure 2B). 


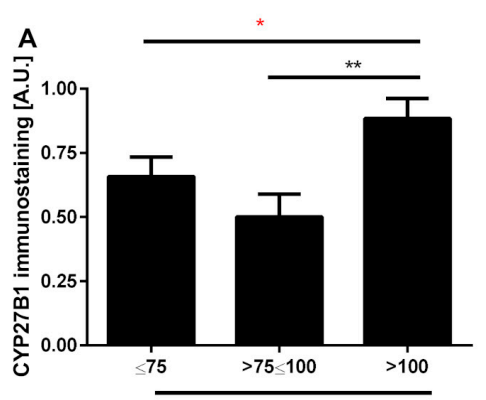

Nuclear ROR $\gamma$ immunostainig [A.U.]

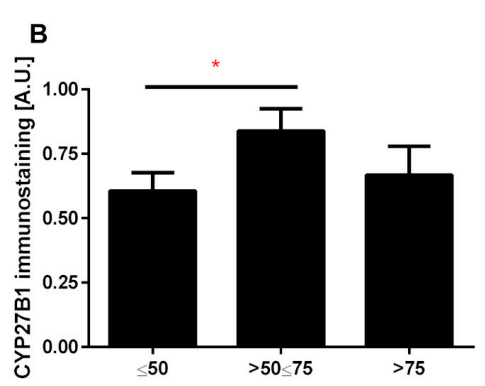

Cytoplasmic ROR $\gamma$ immunostainig [A.U.]
C

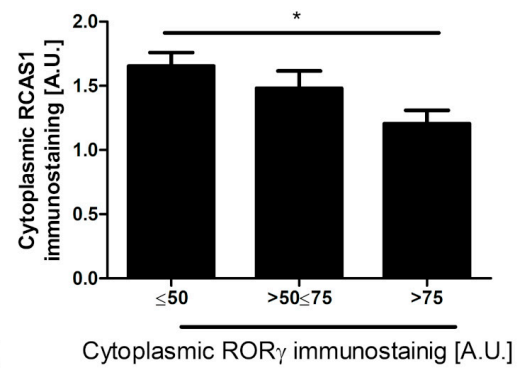

D
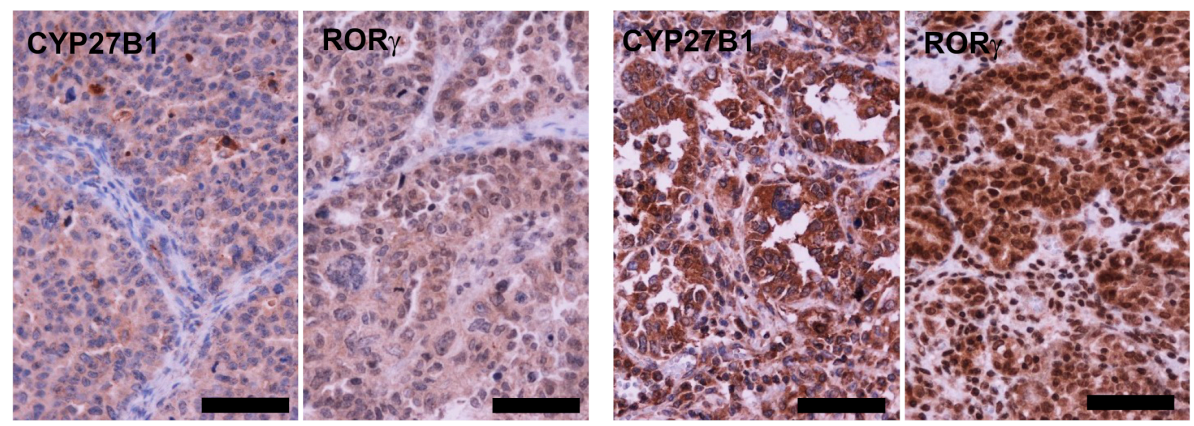

E
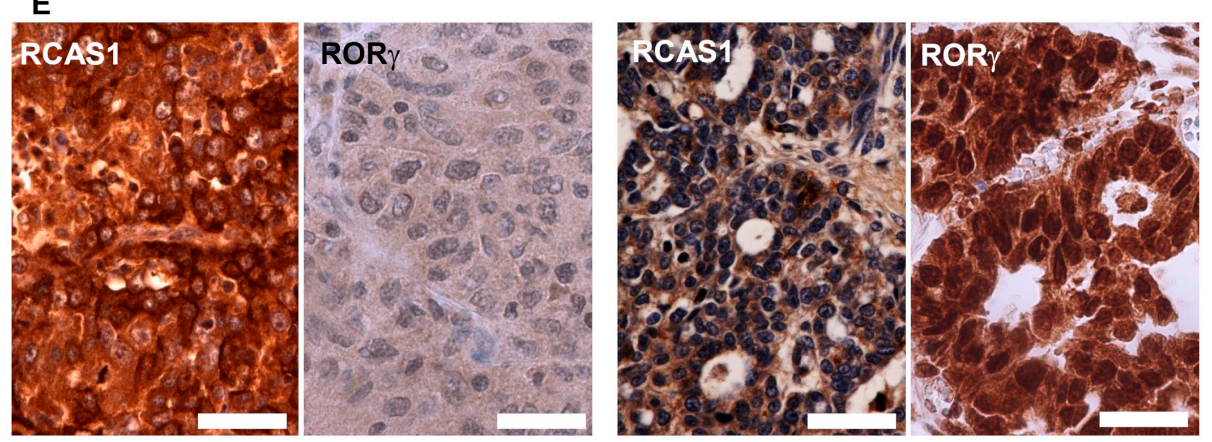

Figure 2. Correlation of nuclear (A) and cytoplasmic (B,C) ROR $\gamma$ immunostaining to cytochrome P450 (CYP)27B1 (A,B) and RCAS1 (receptor binding cancer antigen expressed on SiSo cells) (C) expression in ovarian tumors $(n=63)$. Statistically significant differences are denoted with asterisks as determined by ANOVA (black asterisks) or Student's t-test (red asterisks, ${ }^{*} p<0.05,{ }^{* *} p<0.01$ ). (D) Representative images of CYP27B1 and ROR $\gamma$ immunostaining of two ovarian cancer cases. (E) Representative images of RCAS1 and ROR $\gamma$ immunostaining of two ovarian cancer cases. Scale bars: black $=50 \mu \mathrm{m}$, white $=100 \mu \mathrm{m}$.

Estrogen receptor-binding site-associated antigen (EBAG9, also referred to as RCAS1) is a tumor-associated antigen that is expressed at high frequency in a variety of cancers. It promotes tumor progression by enhancing apoptosis in cytotoxic T lymphocytes, thereby facilitating immune escape and tumor progression [66-68]. Next, we analyzed the relationship between ROR $\gamma$ and RCAS1 expression and found an inverse correlation between their expression levels $(r=-0.2688, p=0.0152$ and $r=-0.3113, p=0.0058$ for cytoplasmic and membrane RCAS1, respectively) with significantly higher RCAS1 expression in cases with cytoplasmic ROR $\gamma$ levels of $\leq 50$ AU (Figure 2C).

\subsection{ROR $y$ Expression Affects Survival of Ovarian Cancer Patients}

$\operatorname{ROR} \gamma$ expression is related to the tumor aggressiveness, and higher proliferation activity, as assessed by the percentage of Ki-67-positive cells, was found in cases with lower nuclear ROR $\gamma$ 
level (Figure S1, Supplementary Materials). Analysis of the overall survival time (OS) revealed that higher ROR $\gamma$ expression in primary cancers was associated with longer overall survival (mean survival of patients without and with cytoplasmic ROR $\gamma$ was 33.4 vs. 43.9 months, respectively, while corresponding values for nuclear ROR $\gamma$ were 30.1 vs. 45.7 months, respectively). Furthermore, disease-free survival (DFS) was affected by disturbances in ROR $\gamma$ expression, and the mean DFS of patients without and with cytoplasmic ROR $\gamma$ was 0.0 vs. 18.8 months, respectively, while these values for nuclear ROR $\gamma$ were 2.4 vs. 16.3 months, respectively. In addition, Kaplan-Meier survival curves showed significant differences for both OS (Figure 3A,B) and DFS (Figure 3C,D) in relation to cytoplasmic (Figure 3A,C) and nuclear ROR $\gamma$ (Figure 3B,D). We did not observe significant differences in OS and DFS with respect to ROR $\gamma$ expression in metastatic cancers.
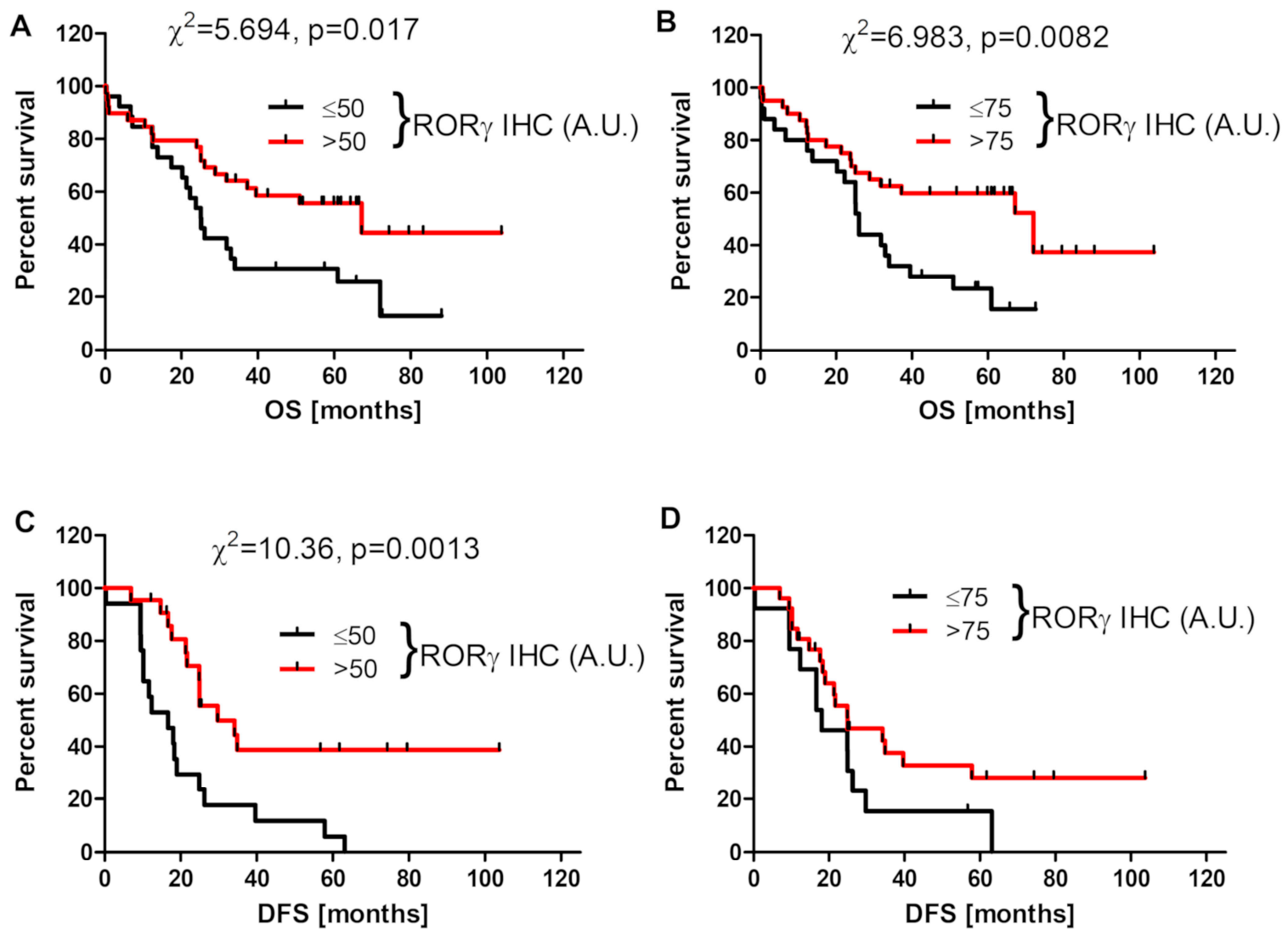

Figure 3. Overall survival (OS) (A,B) and disease-free survival (DFS) (C,D) of ovarian cancer patients in relation to cytoplasmic $(\mathbf{A}, \mathbf{C})$ and nuclear $(\mathbf{B}, \mathbf{D})$ ROR $\gamma$ immunostaining $(n=65)$.

\subsection{VDR Expression Decreases in Human Ovarian Tumors}

Similar to ROR $\gamma$, VDR immunostaining was found predominantly in cell nuclei with very limited cytoplasmic staining. In both primary and metastatic cancers VDR nuclear and cytoplasmic immunostaining decreased in comparison to normal epithelia (Figure $4 \mathrm{~A}-\mathrm{G}$ ). In primary ovarian cancers, a decrease in nuclear VDR immunostaining was negatively correlated with the level of differentiation $(r=-0.40, p=0.0030)$, and the lowest VDR expression was observed in G3 tumors (Figure 4C,D). No correlation was found in nuclear and cytoplasmic VDR staining between primary lesions and metastatic tumors. Nuclear VDR immunostaining correlated negatively with expression of the proliferation marker $\mathrm{Ki}-67$, but this correlation was limited to the central part of the tumor $(r=-0.28, p=0.035)$, defined as the older part of the tumor, with no signs of dynamic growth [60]. 

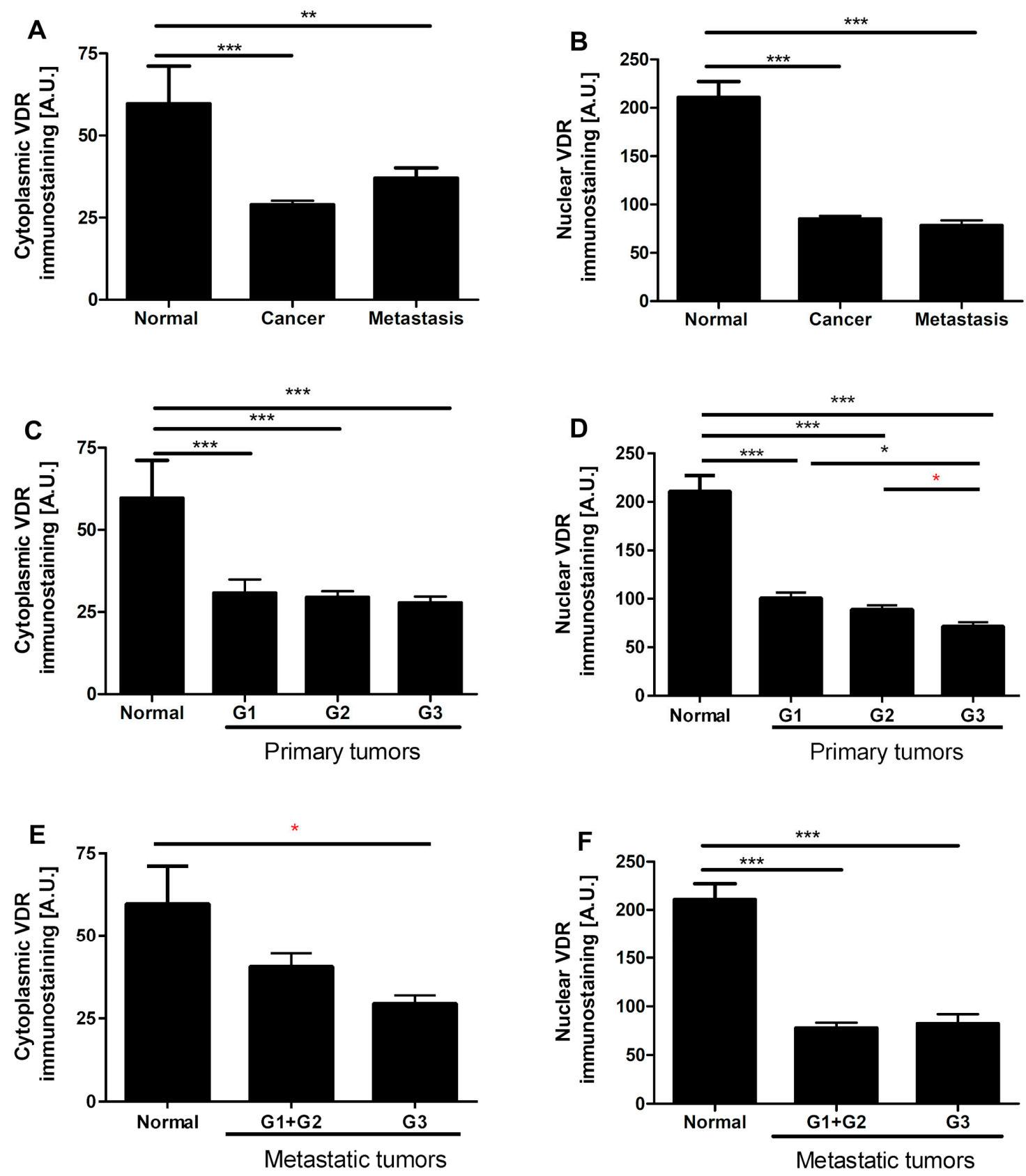

Figure 4. Cont. 


\section{G}
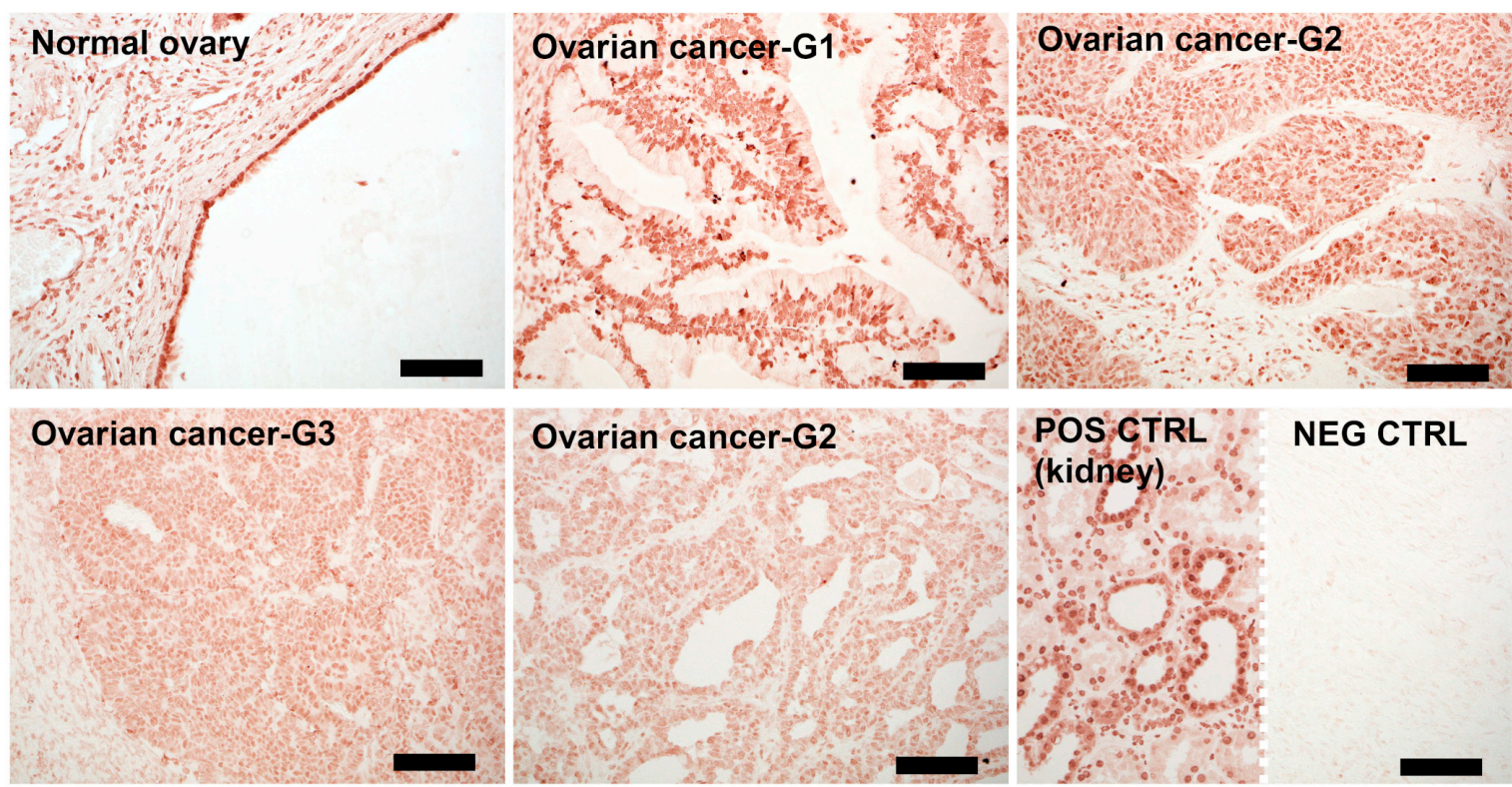

Figure 4. Cytoplasmic and nuclear vitamin D receptor (VDR) immunostaining in normal ovary and ovarian tumors $(n=20)(\mathbf{A}, \mathbf{B})$, in relation to tumors grade in primary tumors $(n=57)$ $(\mathbf{C}, \mathbf{D})$ and in metastatic tumors $(n=13)(\mathbf{E}, \mathbf{F})$. Statistically significant differences are denoted with asterisks as determined by ANOVA (black asterisks) or Student's $t$-test (red asterisks, ${ }^{*} p<0.05$, ** $\left.p<0.01,{ }^{* * *} p<0.001\right)$. (G) Representative VDR immunostaining in normal epithelia, ovarian cancers, and positive (POS CTRL) and negative (NEG CTRL) controls. Scale bars $=50 \mu \mathrm{m}$.

\subsection{VDR Expression Affects Survival of Ovarian Cancer Patients}

Analysis of the OS revealed that VDR expression in primary cancers was associated with longer overall survival (mean survival of patients without and with nuclear VDR was 33.6 vs. 48.8 months, respectively). The significance of these differences was supported by Kaplan-Meier survival curves (Figure 5). For cytoplasmic VDR, there were no differences in OS (not shown). In addition, DFS was not affected by VDR expression in ovarian cancer cells (not shown).

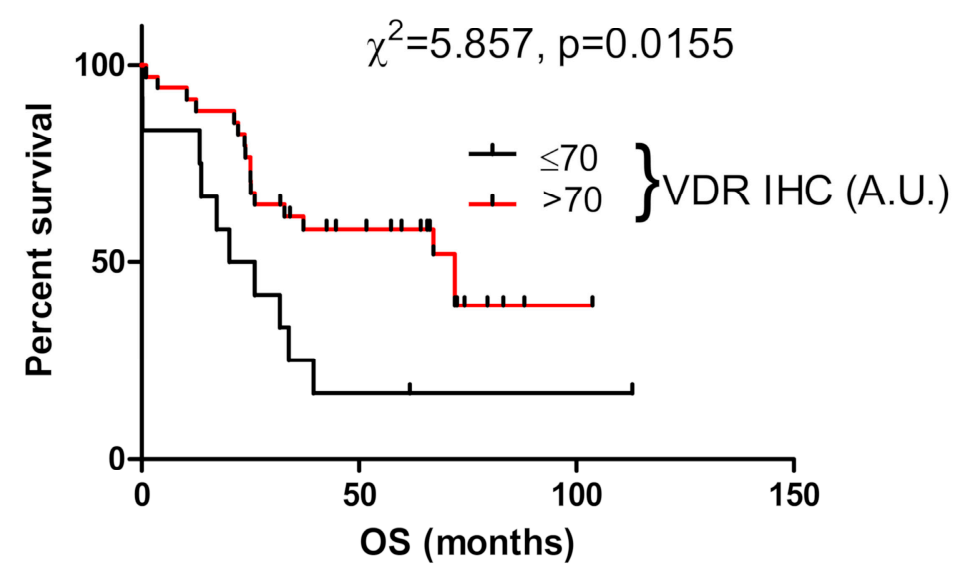

Figure 5. Overall survival (OS) of ovarian cancer patients in relation to nuclear VDR immunostaining $(n=57)$.

\subsection{Expression of RORs and VDR in Human Ovarian Cancer Cell Lines}

Both WB and immunofluorescence (IF) analyses showed expression of VDR, ROR $\gamma$, and ROR $\alpha$ in OVCAR-3 and SKOV-3 ovarian cancer cells, with the latter showing significantly stronger levels 
of expression (Figure 6A-F). Analysis of nuclear and cytoplasmic fractions probed with anti-VDR antibodies again showed a significantly higher signal in the nuclei from SKOV-3 cells (Figure 6A middle panel). Analysis of the cytoplasmic fraction from OVCAR-3 cells showed several bands with molecular weight (MW) higher than expected for VDR (Figure 6A right panel), suggesting processing through ubiquitination, which can give higher-MW species before final degradation [69].
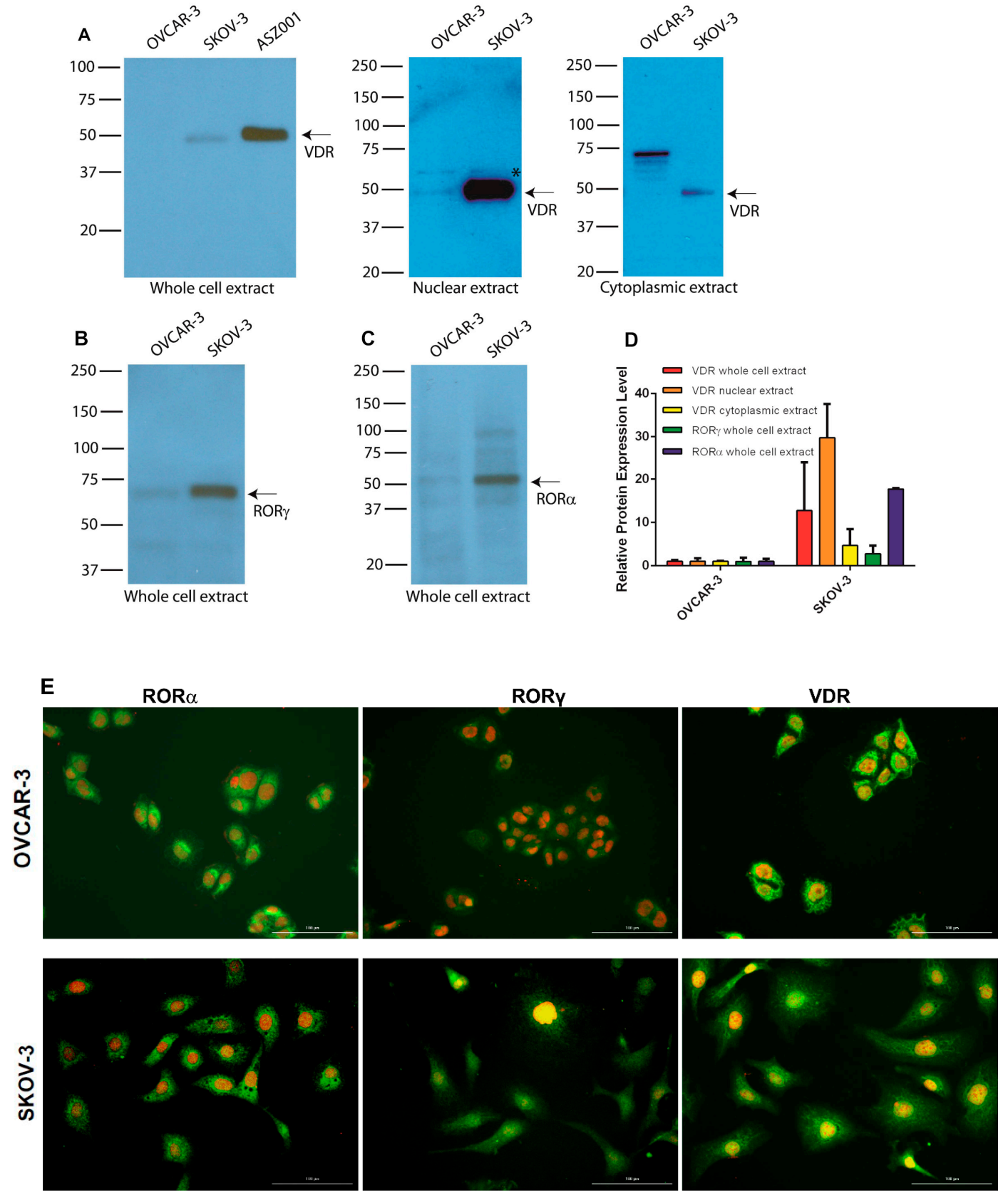

Figure 6. ROR $\alpha, \operatorname{ROR} \gamma$, and VDR in OVCAR-3 and SKOV-3 ovarian cancer cells. Expression of VDR and $\mathrm{ROR} \alpha / \gamma$ in ovarian cancer cell lines as assessed by Western blot (WB): (A) VDR; (B) ROR $\gamma ;(\mathbf{C}) \mathrm{ROR} \alpha$. (D) Relative protein expression in OVCAR-3 and SKOV-3 as measured by WB in whole-cell extracts $(n=2)$ and nuclear $(n=2)$ and cytoplasmic $(n=2)$ fractions. ASZ001 (mouse basal carcinoma cell line) was used as a positive control for VDR expression in panel (A). (E) Immunofluorescence detection of ROR $\alpha, \operatorname{ROR} \gamma$, and VDR in OVCAR-3 and SKOV-3 ovarian cancer cells. Scale bars $=100 \mu \mathrm{m} .{ }^{*} p<0.05$. 
3.7. Effect of Vitamin D3 and Lumisterol Hydroxyderivatives and of Synthetic ROR $\alpha / \gamma$ Agonist, SR1078, on Growth of Ovarian Cancer Lines

Of the compounds tested, $20(\mathrm{OH}) \mathrm{D}_{3}, 20(\mathrm{OH}) \mathrm{L}_{3}$, and SR1078, but not $1,25(\mathrm{OH})_{2} \mathrm{D}_{3}$, inhibited SKOV-3 growth in a dose-dependent manner as assessed by the MTS assay (Figure 7).
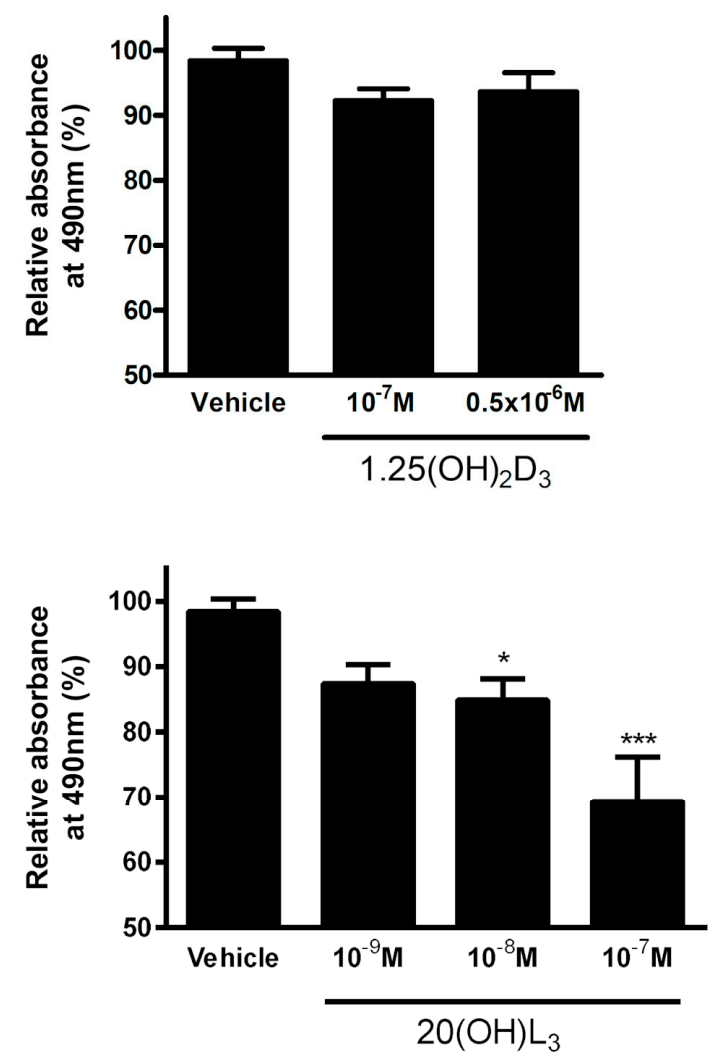
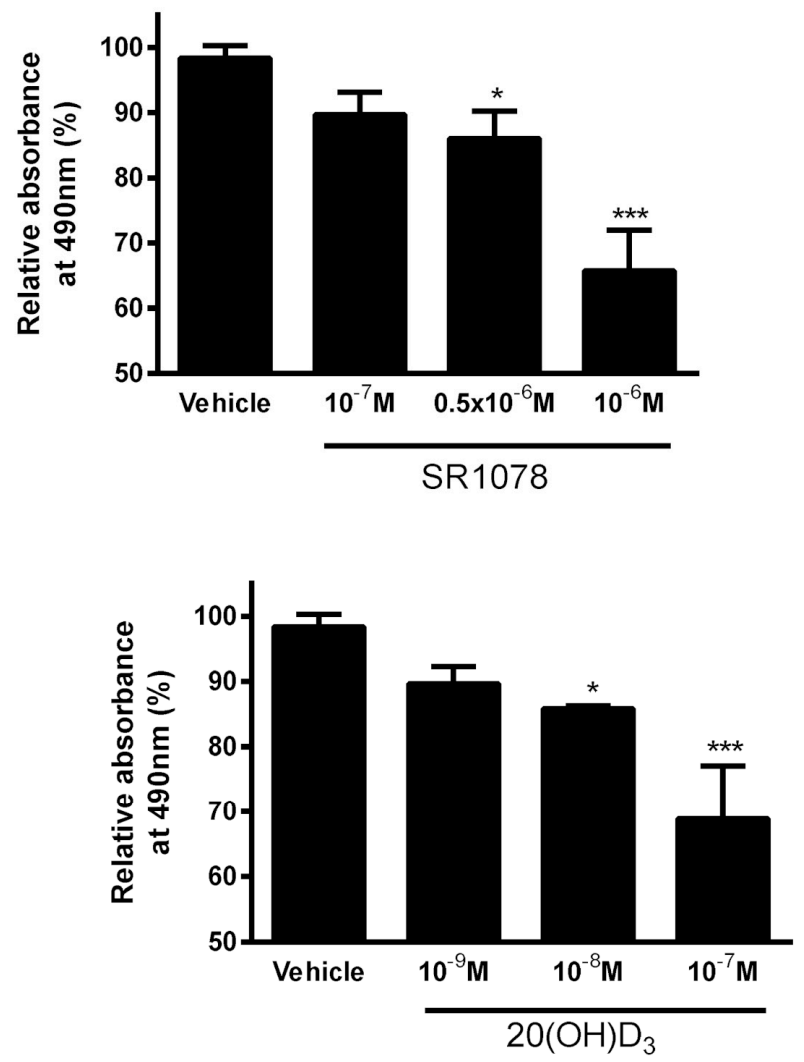

Figure 7. Effects of 1,25(OH)2D3, 20(OH)D3, 20(OH) $\mathrm{L}_{3}$, and SR1078 on proliferation of SKOV3 ovarian cancer cell line as assayed with the MTS (3-(4,5-dimethylthiazol-2-yl)-5-(3-carboxymethoxyphenyl)-2-(4-sulfophenyl)-2H-tetrazolium) test $(n=3)$. Data are presented as a percentage of the control. Statistically significant differences are denoted with asterisks as determined by ANOVA $\left({ }^{*} p<0.05,{ }^{* * *} p<0.001\right)$.

In OVCAR-3 cells $1,25(\mathrm{OH})_{2} \mathrm{D}_{3}, 20(\mathrm{OH}) \mathrm{L}_{3}$, and SR1078 inhibited cell proliferation in a dose-dependent manner, whereas $20(\mathrm{OH}) \mathrm{D}_{3}$ had no significant effect (Figure 8 ). 

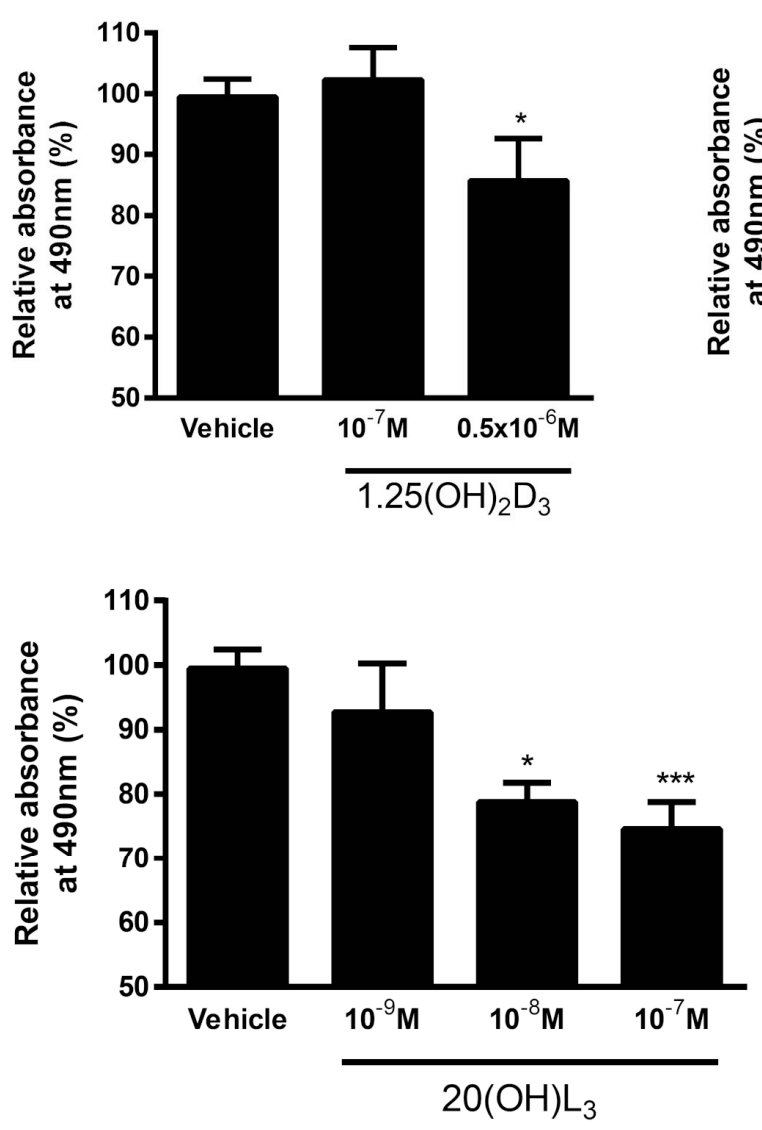
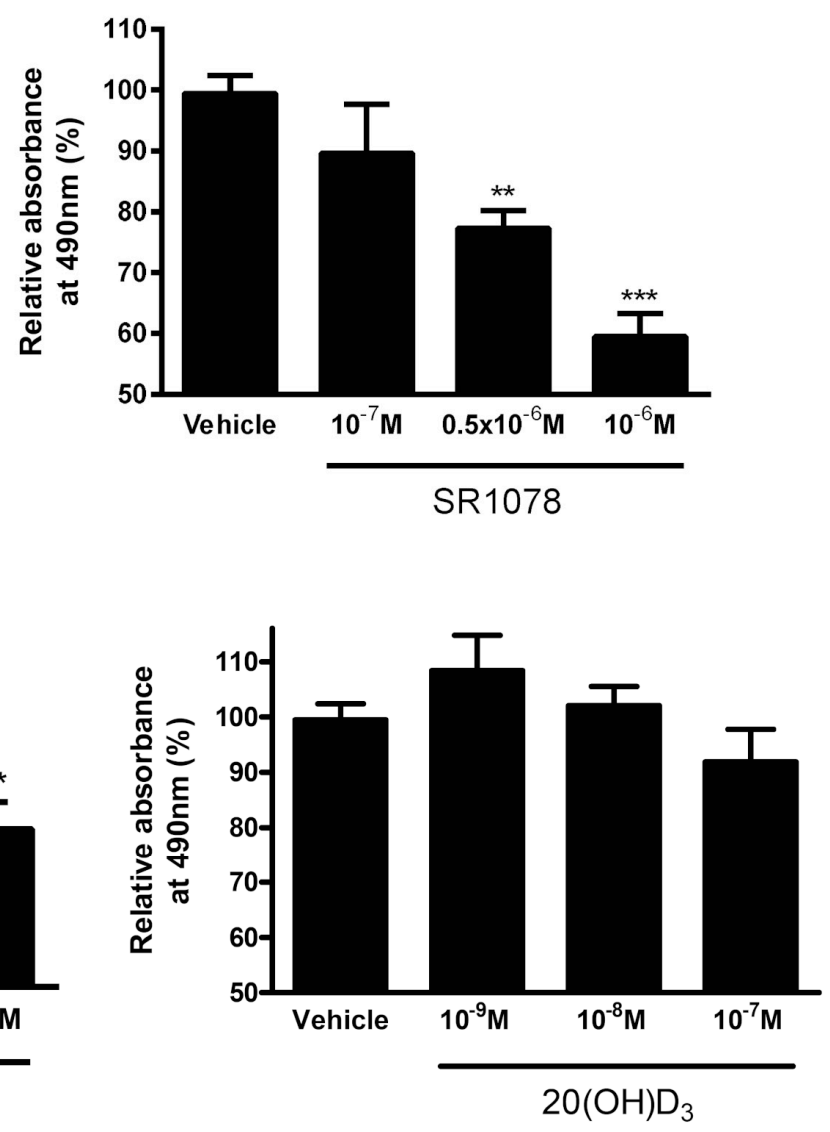

Figure 8. Effect of 1,25(OH)2D3, 20(OH)D3, 20(OH)L $\mathrm{L}_{3}$, and SR1078 on proliferation of OVCAR3 ovarian cancer cell line as assayed with MTS test $(n=3)$. Data are presented as a percentage of the control. Statistically significant differences are denoted with asterisks as determined by ANOVA $(* p<0.05$, ** $p<0.01$, and $\left.{ }^{* * *} p<0.001\right)$.

The ability of cancer cells to form spheroids in vitro is often used as the assay to assess the anchorage-independent growth and/or stem-cell-like phenotype or the antitumor effect of drugs. Accordingly, we assessed the effects of $1,25(\mathrm{OH})_{2} \mathrm{D}_{3}, 20(\mathrm{OH}) \mathrm{D}_{3}, 20(\mathrm{OH}) \mathrm{L}_{3}$, and SR1078 on spheroid formation by the SKOV-3 cell line. Tests on OVCAR-3 cells were not performed since these cells did not form spheroids in vitro. While $1,25(\mathrm{OH})_{2} \mathrm{D}_{3}, 20(\mathrm{OH}) \mathrm{L}_{3}$, and SR1078 reduced spheroid formation in a dose-dependent manner, $20(\mathrm{OH}) \mathrm{D}_{3}$ showed no effect in the dose range $10^{-9}$ to $10^{-7} \mathrm{M}$ (Figure 9). 

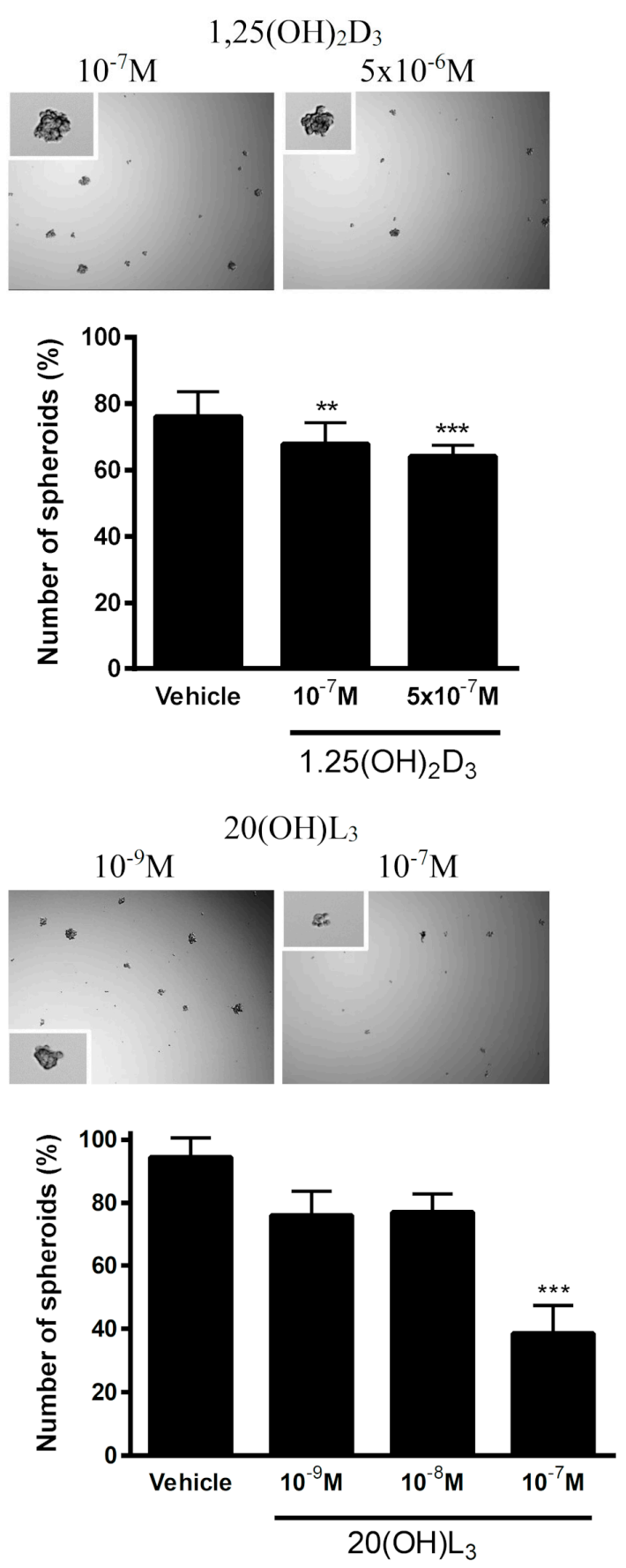
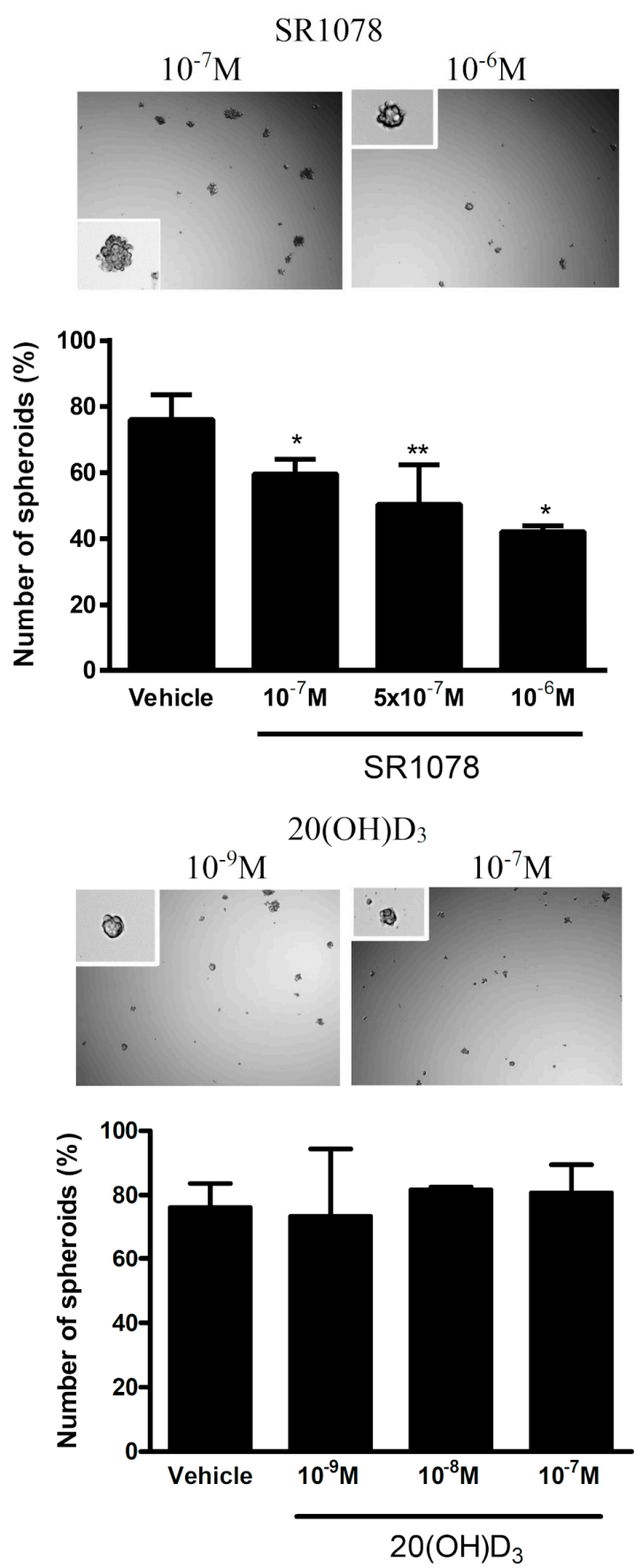

Figure 9. Effect of $1,25(\mathrm{OH})_{2} \mathrm{D}_{3}, 20(\mathrm{OH}) \mathrm{D}_{3}, 20(\mathrm{OH}) \mathrm{L}_{3}$, and SR1078 spheroid formation by SKOV-3 ovarian cancer cell line $(n=3)$. Data are presented as a percentage of the control. Statistically significant differences are denoted with asterisks as determined by ANOVA ${ }^{*} p<0.05,{ }^{* *} p<0.01$, and $\left.{ }^{* * *} p<0.001\right)$. Images present representative spheroids, and insets present high-magnification images of single spheroids.

\section{Discussion}

In this study, we analyzed the expression of $\operatorname{ROR} \alpha, \operatorname{ROR} \gamma$, and VDR in ovarian tumor cells and identified an inverse correlation between their expression and a more aggressive phenotype and unfavorable clinical outcome. To the best of our knowledge, this is the first report showing the expression of ROR $\gamma$ in clinical OC samples. While the expression of VDR in OCs has been reported in several studies, some of these reports present contradictory data. Villena-Heinsen et al. [70] observed 
VDR expression in more than $83 \%$ of normal ovaries $(n=14)$ and $100 \%$ of ovarian cancers $(n=40)$. Similarly, Friedrich et al. [71] found an increased expression of VDR (assessed by immunohistochemistry and PCR) in cancers in comparison to normal ovaries. In our cancer samples and consistent with the observations by Thill et al. [72] and Cordes et al. [73], VDR expression was heterogeneous, but the semiquantitative analysis indicated lower VDR levels in cancers than in normal ovaries (Figure 4). While the paper was under review Pejovic et al. [74] published similar association on vitamin D signaling and ovarian cancer. Reduced VDR expression in malignant tissues was also found in other tumors, such as cutaneous and uveal melanomas [54,55,75], urothelial bladder [56], colon [76], and lung [77] cancers. In some tumors, the reduced expression of VDR correlated to worse prognosis.

Similarly to VDR, we also showed lower ROR $\gamma$ expression in ovarian cancers in comparison to normal tissues. This decreased ROR $\gamma$ level was associated with a poorer prognosis (Figures 1 and 3). These observations are in agreement with previous reports showing the reduced expression of RORs in other tumors, such as cutaneous and uveal melanomas [48,52,75], hepatoma cells [78], and breast cancers [79]. Increased ROR $\gamma$ expression corresponded to a better prognosis and clinical outcome for patients with the above tumors $[52,75,80]$. Our previous study showed reduced CYP27B1 levels in primary and metastatic ovarian cancers compared normal controls, with the strongest reduction found in cancers showing a high proliferation index, lack of immune response, presence of necrosis, and dynamic tumor growth. In addition, a lack of CYP27B1 expression affected the overall survival time [40]. The current study uncovered a correlation between higher ROR $\gamma$ expression and higher CYP27B1 expression (Figure 2).

We also assessed the in vitro phenotypic impact of $1,25(\mathrm{OH})_{2} \mathrm{D}_{3}, 20(\mathrm{OH}) \mathrm{D}_{3}, 20(\mathrm{OH}) \mathrm{L}_{3}$, and SR1078 on OC cells and found that the inhibition of proliferation was affected by the chemical nature of the molecules tested (Figures 7-9). This anticancer activity of vitamin D derivatives against OC cells is in line with other studies showing a reduction in cancer cell proliferation, but some differences in these effects were observed. $20(\mathrm{OH}) \mathrm{L}_{3}$ and synthetic ROR $\alpha / \mathrm{ROR} \gamma$ agonist, SR1078, inhibited proliferation in both cell lines, while $20(\mathrm{OH}) \mathrm{D}_{3}$ only inhibited the SKOV-3 cell proliferation. $1,25(\mathrm{OH})_{2} \mathrm{D}_{3}, 20(\mathrm{OH}) \mathrm{L}_{3}$, and SR1078, but not $20(\mathrm{OH}) \mathrm{D}_{3}$, inhibited spheroid formation in SKOV-3 cells (Figures 7-9). The variation in the response of OVCAR-3 and SKOV-3 cell lines could result from the differential expression of VDR, $\operatorname{ROR} \alpha$, and $\operatorname{ROR} \gamma$ (Figure 6). Previously, we showed that $1,20(\mathrm{OH})_{2} \mathrm{D}_{3}$ and $20(\mathrm{OH}) \mathrm{D}_{3}$ inhibit the proliferation of human melanomas cells and CAL-27 oral squamous cell carcinoma [20,21,81,82]. The antitumor activity of SR1078 was previously reported for MCF-7 and MDA-MB-231 breast cancer cells [79]. Our results for vitamin D hydroxyderivatives are in agreement with previous publications regarding the effects of vitamin $\mathrm{D}$ and its derivatives on ovarian cancer cells. In mouse ovarian surface epithelial cells, calcitriol delayed malignant transformation induced with 7,12-dimethylbenz[a]anthracene (DMBA) and decreased colony formation in soft agar [83]. Vitamin D stimulated the expression of VDR and reduced the metastatic potential of ovarian cancer cells by increasing E-cadherin and decreasing the expression of $\beta$-catenin both in vivo and in vitro [83], while, in OVCAR-3 and SKOV-3 ovarian cancer cells, calcitriol showed antiproliferative effects with an additive effect with celecoxib [84]. Furthermore, the growth of OVCAR-3 tumor xenografts in nude mice was inhibited by the vitamin D analogue, EB1089 (seocalcitol), while calcitriol and EB1089 inhibited the growth of OVCAR-3 cells [85]. OVCAR-3 cells are also sensitive to inhibition of migration and invasion into the omentum by calcitriol in ex vivo mouse models [86]. The expression of VDR in cancer and in stromal cells is important for the inhibition of invasion of OC cells by vitamin D or its analogue, EB1089 (as found in VDR null mouse) [86]. The inhibition of cancer growth by calcitriol can be mediated via regulation of miR-498 and telomerase activity [87]. Correspondingly, the ROR agonist, SR1078, was able to enhance the anticancer effect of vitamin D [88]. In addition, SR1078 stabilized p53 in cancer cells, thereby increasing p53 function and apoptosis [89]. 


\section{Conclusions}

In conclusion, our results demonstrate the anticancer properties of $1,25(\mathrm{OH})_{2} \mathrm{D}_{3}, 20(\mathrm{OH}) \mathrm{D}_{3}$, and $20(\mathrm{OH}) \mathrm{L}_{3}$ against OCs cells. Importantly, the decreased expression of ROR $\gamma$ and VDR in ovarian tumor cells correlates with a more aggressive behavior and negative patient outcome. We also suggest that modulation of VDR and ROR $\gamma$ activities with their agonists could affect ovarian cancer cell behavior, suggesting their usefulness as potential targets in ovarian cancer therapy.

Supplementary Materials: The following are available online at http://www.mdpi.com/2072-6643/12/11/3541/s1: Figure S1. Summary of ROR $\alpha$ expression in ovarian cancer samples; Table S1. Summary of ROR $\alpha$ expression in ovarian cancer samples.

Author Contributions: A.A.B. designed the study, coordinated the experiments, participated in clinico-pathological and cell culture-based studies, collected the data, performed analysis, and wrote the manuscript; T.-K.K. performed the WB experiments and collected the experimental data; M.Z. participated in the experimental work and collected the clinical data; W.J. performed pathological examination; J.Y. provided cell lines and worked on the manuscript; R.C.T. provided the vitamin $\mathrm{D}$ and lumisterol derivatives and worked on the manuscript; A.M.J. provided anti-ROR antibodies and worked on the manuscript; A.T.S. designed the study, coordinated the experiments, analyzed data, worked on the manuscript, and secured the funding. All authors have read and agreed to the published version of the manuscript.

Funding: This study was supported in part by funds for statutory research from Nicolaus Copernicus University [A.A.B.], NIH grants: 1R01AR073004-01A1, R01AR071189-01A1 and R21 AI149267-01A1 [A.T.S.], VA merit grant no. 1I01BX004293-01A1) [A.T.S. and the Intramural Research Program of the NIEHS, NIH Z01-ES-101586 [A.M.J.].

Conflicts of Interest: The authors declare no conflict of interest.

\section{References}

1. Ovarian Cancer Statistics. Available online: https://www.wcrf.org/dietandcancer/cancer-trends/ovariancancer-statistics (accessed on 20 February 2019).

2. Bhatla, N.; Jones, A. The World Ovarian Cancer Coalition Atlas. Glob. Trends Incid. Mortal. Surviv. 2018, 2018. Available online: https://www.google.com/url?sa=t\&rct=j\&q=\&esrc=s\&source= web\&cd=\&ved=2ahUKEwilsaWq-YbtAhXfCRAIHZawAwMQFjAAegQIBhAC\&url=https\%3A\% 2F\%2Fworldovariancancercoalition.org\%2Fwp-content\%2Fuploads\%2F2018\%2F10\%2FTHE-WORLDOVARIAN-CANCER-COALITION-ATLAS-2018.pdf\&usg=AOvVaw0YOF_op8eT7tUZBY8MPUtO (accessed on 20 February 2019).

3. Colombo, N.; Van Gorp, T.; Parma, G.; Amant, F.; Gatta, G.; Sessa, C.; Vergote, I. Ovarian cancer. Crit. Rev. Oncol. Hematol. 2006, 60, 159-179. [CrossRef]

4. Capriglione, S.; Luvero, D.; Plotti, F.; Terranova, C.; Montera, R.; Scaletta, G.; Schiro, T.; Rossini, G.; Benedetti Panici, P.; Angioli, R. Ovarian cancer recurrence and early detection: May HE4 play a key role in this open challenge? A systematic review of literature. Med. Oncol. 2017, 34, 164. [CrossRef]

5. Ozga, M.; Aghajanian, C.; Myers-Virtue, S.; McDonnell, G.; Jhanwar, S.; Hichenberg, S.; Sulimanoff, I. A systematic review of ovarian cancer and fear of recurrence. Palliat. Support. Care 2015, 13, 1771-1780. [CrossRef] [PubMed]

6. Ma, Y.; Yu, W.D.; Trump, D.L.; Johnson, C.S. 1,25D3 enhances antitumor activity of gemcitabine and cisplatin in human bladder cancer models. Cancer 2010, 116, 3294-3303. [CrossRef] [PubMed]

7. Pelczynska, M.; Switalska, M.; Maciejewska, M.; Jaroszewicz, I.; Kutner, A.; Opolski, A. Antiproliferative activity of vitamin D compounds in combination with cytostatics. Anticancer Res. 2006, 26, 2701-2705. [PubMed]

8. Wietrzyk, J.; Milczarek, M.; Kutner, A. The effect of combined treatment on head and neck human cancer cell lines with novel analogs of calcitriol and cytostatics. Oncol. Res. 2007, 16, 517-525. [CrossRef] [PubMed]

9. Wietrzyk, J.; Nevozhay, D.; Filip, B.; Milczarek, M.; Kutner, A. The antitumor effect of lowered doses of cytostatics combined with new analogs of vitamin D in mice. Anticancer Res. 2007, 27, 3387-3398.

10. Chaudhary, K.S.; Abel, P.D.; Stamp, G.W.; Lalani, E. Differential expression of cell death regulators in response to thapsigargin and adriamycin in Bcl-2 transfected DU145 prostatic cancer cells. J. Pathol. 2001, 193, 522-529. [CrossRef] 
11. Dunlap, N.; Schwartz, G.G.; Eads, D.; Cramer, S.D.; Sherk, A.B.; John, V.; Koumenis, C. 1alpha,25-dihydroxyvitamin $\mathrm{D}(3)$ (calcitriol) and its analogue, 19-nor-1alpha,25(OH)(2) $\mathrm{D}(2)$, potentiate the effects of ionising radiation on human prostate cancer cells. Br. J. Cancer 2003, 89, 746-753. [CrossRef]

12. Podgorska, E.; Drzal, A.; Matuszak, Z.; Swakon, J.; Slominski, A.; Elas, M.; Urbanska, K. Calcitriol and Calcidiol Can Sensitize Melanoma Cells to Low(-)LET Proton Beam Irradiation. Int. J. Mol. Sci. 2018, 19, 2336. [CrossRef]

13. Polar, M.K.; Gennings, C.; Park, M.; Gupta, M.S.; Gewirtz, D.A. Effect of the vitamin D3 analog ILX 23-7553 on apoptosis and sensitivity to fractionated radiation in breast tumor cells and normal human fibroblasts. Cancer Chemother. Pharmacol. 2003, 51, 415-421. [CrossRef] [PubMed]

14. Sundaram, S.; Gewirtz, D.A. The vitamin D3 analog EB 1089 enhances the response of human breast tumor cells to radiation. Radiat. Res. 1999, 152, 479-486. [CrossRef] [PubMed]

15. Sundaram, S.; Sea, A.; Feldman, S.; Strawbridge, R.; Hoopes, P.J.; Demidenko, E.; Binderup, L.; Gewirtz, D.A. The combination of a potent vitamin D3 analog, EB 1089, with ionizing radiation reduces tumor growth and induces apoptosis of MCF-7 breast tumor xenografts in nude mice. Clin. Cancer Res. 2003, 9, 2350-2356. [PubMed]

16. Weitsman, G.E.; Koren, R.; Zuck, E.; Rotem, C.; Liberman, U.A.; Ravid, A. Vitamin D sensitizes breast cancer cells to the action of $\mathrm{H}_{2} \mathrm{O}_{2}$ : Mitochondria as a convergence point in the death pathway. Free Radic. Biol. Med. 2005, 39, 266-278. [CrossRef]

17. Bikle, D.D. Vitamin D metabolism, mechanism of action, and clinical applications. Chem. Biol. 2014, 21, 319-329. [CrossRef]

18. Fleet, J.C.; DeSmet, M.; Johnson, R.; Li, Y. Vitamin D and cancer: A review of molecular mechanisms. Biochem. J. 2011, 441, 61-76. [CrossRef]

19. Slominski, A.T.; Janjetovic, Z.; Fuller, B.E.; Zmijewski, M.A.; Tuckey, R.C.; Nguyen, M.N.; Sweatman, T.; Li, W.; Zjawiony, J.; Miller, D.; et al. Products of vitamin D3 or 7-dehydrocholesterol metabolism by cytochrome P450scc show anti-leukemia effects, having low or absent calcemic activity. PLoS ONE 2010, 5, e9907. [CrossRef]

20. Slominski, A.T.; Janjetovic, Z.; Kim, T.K.; Wright, A.C.; Grese, L.N.; Riney, S.J.; Nguyen, M.N.; Tuckey, R.C. Novel vitamin D hydroxyderivatives inhibit melanoma growth and show differential effects on normal melanocytes. Anticancer Res. 2012, 32, 3733-3742.

21. Skobowiat, C.; Oak, A.S.; Kim, T.K.; Yang, C.H.; Pfeffer, L.M.; Tuckey, R.C.; Slominski, A.T. Noncalcemic 20-hydroxyvitamin D3 inhibits human melanoma growth in in vitro and in vivo models. Oncotarget 2016. [CrossRef]

22. Slominski, A.T.; Brozyna, A.A.; Skobowiat, C.; Zmijewski, M.A.; Kim, T.K.; Janjetovic, Z.; Oak, A.S.; Jozwicki, W.; Jetten, A.M.; Mason, R.S.; et al. On the role of classical and novel forms of vitamin D in melanoma progression and management. J. Steroid Biochem. Mol. Biol. 2018, 177, 159-170. [CrossRef] [PubMed]

23. Holick, M.F. Vitamin D: A d-lightful solution for health. J. Investig. Med. 2011, 59, 872-880. [CrossRef] [PubMed]

24. Holick, M.F.; Chen, T.C.; Lu, Z.; Sauter, E. Vitamin D and skin physiology: A D-lightful story. J. Bone Miner. Res. 2007, 22 (Suppl. 2), V28-V33. [CrossRef]

25. Holick, M.F. Biological Effects of Sunlight, Ultraviolet Radiation, Visible Light, Infrared Radiation and Vitamin D for Health. Anticancer Res. 2016, 36, 1345-1356. [PubMed]

26. Holick, M.F. Sunlight, ultraviolet radiation, vitamin D and skin cancer: How much sunlight do we need? Adv. Exp. Med. Biol. 2014, 810,1-16. [PubMed]

27. Bikle, D.D. Vitamin D: Newer Concepts of Its Metabolism and Function the Basic and Clinical Level. J. Endocr. Soc. 2020, 4, bvz038. [CrossRef] [PubMed]

28. Bikle, D.; Christakos, S. New aspects of vitamin D metabolism and action-Addressing the skin as source and target. Nat. Rev. Endocrinol. 2020. [CrossRef] [PubMed]

29. Bouillon, R.; Marcocci, C.; Carmeliet, G.; Bikle, D.; White, J.H.; Dawson-Hughes, B.; Lips, P.; Munns, C.F.; Lazaretti-Castro, M.; Giustina, A.; et al. Skeletal and Extraskeletal Actions of Vitamin D: Current Evidence and Outstanding Questions. Endocr. Rev. 2019, 40, 1109-1151. [CrossRef]

30. Bikle, D.D. Extraskeletal actions of vitamin D. Ann. N. Y. Acad. Sci. 2016, 1376, 29-52. [CrossRef]

31. Slominski, A.T.; Zmijewski, M.A.; Plonka, P.M.; Szaflarski, J.P.; Paus, R. How UV Light Touches the Brain and Endocrine System Through Skin, and Why. Endocrinology 2018, 159, 1992-2007. [CrossRef] 
32. Jenkinson, C. The vitamin D metabolome: An update on analysis and function. Cell Biochem. Funct. 2019. [CrossRef] [PubMed]

33. Tuckey, R.C.; Cheng, C.Y.S.; Slominski, A.T. The serum vitamin D metabolome: What we know and what is still to discover. J. Steroid Biochem. Mol. Biol. 2019, 186, 4-21. [CrossRef] [PubMed]

34. Slominski, A.T.; Li, W.; Kim, T.K.; Semak, I.; Wang, J.; Zjawiony, J.K.; Tuckey, R.C. Novel activities of CYP11A1 and their potential physiological significance. J. Steroid Biochem. Mol. Biol. 2015, 151, 25-37. [CrossRef] [PubMed]

35. Slominski, A.T.; Kim, T.K.; Li, W.; Postlethwaite, A.; Tieu, E.W.; Tang, E.K.Y.; Tuckey, R.C. Detection of novel CYP11A1-derived secosteroids in the human epidermis and serum and pig adrenal gland. Sci. Rep. 2015, 5, 14875. [CrossRef] [PubMed]

36. Slominski, A.T.; Kim, T.K.; Hobrath, J.V.; Janjetovic, Z.; Oak, A.S.W.; Postlethwaite, A.; Lin, Z.; Li, W.; Takeda, Y.; Jetten, A.M.; et al. Characterization of a new pathway that activates lumisterol in vivo to biologically active hydroxylumisterols. Sci. Rep. 2017, 7, 11434. [CrossRef]

37. Slominski, A.T.; Chaiprasongsuk, A.; Janjetovic, Z.; Kim, T.K.; Stefan, J.; Slominski, R.M.; Hanumanthu, V.S.; Raman, C.; Qayyum, S.; Song, Y.; et al. Photoprotective Properties of Vitamin D and Lumisterol Hydroxyderivatives. Cell Biochem. Biophys. 2020, 78, 165-180. [CrossRef] [PubMed]

38. Ong, J.S.; Cuellar-Partida, G.; Lu, Y.; Fasching, P.A.; Hein, A.; Burghaus, S.; Beckmann, M.W.; Lambrechts, D.; Van Nieuwenhuysen, E.; Vergote, I.; et al. Association of vitamin D levels and risk of ovarian cancer: A Mendelian randomization study. Int. J. Epidemiol. 2016, 45, 1619-1630. [CrossRef]

39. Webb, P.M.; de Fazio, A.; Protani, M.M.; Ibiebele, T.I.; Nagle, C.M.; Brand, A.H.; Blomfield, P.I.; Grant, P.; Perrin, L.C.; Neale, R.E. Circulating 25-hydroxyvitamin D and survival in women with ovarian cancer. Am. J. Clin. Nutr. 2015, 102, 109-114. [CrossRef]

40. Brozyna, A.A.; Jozwicki, W.; Jochymski, C.; Slominski, A.T. Decreased expression of CYP27B1 correlates with the increased aggressiveness of ovarian carcinomas. Oncol. Rep. 2014, 33, 599-606. [CrossRef]

41. Slominski, A.T.; Zmijewski, M.A.; Semak, I.; Zbytek, B.; Pisarchik, A.; Li, W.; Zjawiony, J.; Tuckey, R.C. Cytochromes p450 and skin cancer: Role of local endocrine pathways. Anticancer Agents Med. Chem. 2014, 14, 77-96. [CrossRef]

42. Nurminen, V.; Neme, A.; Seuter, S.; Carlberg, C. The impact of the vitamin D-modulated epigenome on VDR target gene regulation. Biochim. Biophys. Acta Gene Regul. Mech. 2018, 1861, 697-705. [CrossRef] [PubMed]

43. Neme, A.; Seuter, S.; Malinen, M.; Nurmi, T.; Tuomainen, T.P.; Virtanen, J.K.; Carlberg, C. In vivo transcriptome changes of human white blood cells in response to vitamin D. J. Steroid Biochem. Mol. Biol. 2018. [CrossRef] [PubMed]

44. Seuter, S.; Neme, A.; Carlberg, C. Epigenome-wide effects of vitamin D and their impact on the transcriptome of human monocytes involve CTCF. Nucleic Acids Res. 2015, 44, 4090-4104. [CrossRef] [PubMed]

45. Silvagno, F.; Consiglio, M.; Foglizzo, V.; Destefanis, M.; Pescarmona, G. Mitochondrial translocation of vitamin $\mathrm{D}$ receptor is mediated by the permeability transition pore in human keratinocyte cell line. PLoS ONE 2013, 8, e54716. [CrossRef]

46. Carlberg, C. Vitamin D Genomics: From In Vitro to In Vivo. Front. Endocrinol. 2018, 9, 250. [CrossRef]

47. Slominski, A.T.; Kim, T.K.; Hobrath, J.V.; Oak, A.S.W.; Tang, E.K.Y.; Tieu, E.W.; Li, W.; Tuckey, R.C.; Jetten, A.M. Endogenously produced nonclassical vitamin D hydroxy-metabolites act as "biased" agonists on VDR and inverse agonists on RORalpha and RORgamma. J. Steroid Biochem. Mol. Biol. 2016, 173, 42-56. [CrossRef]

48. Slominski, A.T.; Kim, T.K.; Takeda, Y.; Janjetovic, Z.; Brozyna, A.A.; Skobowiat, C.; Wang, J.; Postlethwaite, A.; Li, W.; Tuckey, R.C.; et al. RORalpha and ROR gamma are expressed in human skin and serve as receptors for endogenously produced noncalcemic 20-hydroxy- and 20,23-dihydroxyvitamin D. FASEB J. 2014, 28, 2775-2789. [CrossRef]

49. Cook, D.N.; Kang, H.S.; Jetten, A.M. Retinoic Acid-Related Orphan Receptors (RORs): Regulatory Functions in Immunity, Development, Circadian Rhythm, and Metabolism. Nucl. Recept. Res. 2016, 2. [CrossRef]

50. Jetten, A.M.; Takeda, Y.; Slominski, A.; Kang, H.S. Retinoic acid-related Orphan Receptor gamma (RORgamma): Connecting sterol metabolism to regulation of the immune system and autoimmune disease. Curr. Opin. Toxicol. 2018, 8, 66-80. [CrossRef]

51. Jetten, A.M. Retinoid-related orphan receptors (RORs): Critical roles in development, immunity, circadian rhythm, and cellular metabolism. Nucl. Recept. Signal. 2009, 7, e003. [CrossRef] 
52. Brozyna, A.A.; Jozwicki, W.; Skobowiat, C.; Jetten, A.; Slominski, A.T. RORalpha and RORgamma expression inversely correlates with human melanoma progression. Oncotarget 2016, 7, 63261-63282. [CrossRef] [PubMed]

53. Brozyna, A.A.; Jozwicki, W.; Jetten, A.M.; Slominski, A.T. On the relationship between VDR, RORalpha and RORgamma receptors expression and HIF1-alpha levels in human melanomas. Exp. Dermatol. 2019, 28, 1036-1043. [CrossRef] [PubMed]

54. Brozyna, A.A.; Jozwicki, W.; Janjetovic, Z.; Slominski, A.T. Expression of vitamin D receptor decreases during progression of pigmented skin lesions. Hum. Pathol. 2011, 42, 618-631. [CrossRef] [PubMed]

55. Brozyna, A.A.; Jozwicki, W.; Slominski, A.T. Decreased VDR expression in cutaneous melanomas as marker of tumor progression: New data and analyses. Anticancer Res. 2014, 34, 2735-2743. [PubMed]

56. Jozwicki, W.; Brozyna, A.A.; Siekiera, J.; Slominski, A.T. Expression of Vitamin D Receptor (VDR) Positively Correlates with Survival of Urothelial Bladder Cancer Patients. Int. J. Mol. Sci. 2015, 16, 24369-24386. [CrossRef] [PubMed]

57. Takeda, Y.; Jothi, R.; Birault, V.; Jetten, A.M. RORgamma directly regulates the circadian expression of clock genes and downstream targets in vivo. Nucleic Acids Res. 2012, 40, 8519-8535. [CrossRef]

58. Brozyna, A.A.; Jozwicki, W.; Janjetovic, Z.; Slominski, A.T. Expression of the vitamin D-activating enzyme 1alpha-hydroxylase (CYP27B1) decreases during melanoma progression. Hum. Pathol. 2013, 44, 374-387. [CrossRef]

59. Jozwicki, W.; Brozyna, A.A.; Siekiera, J.; Slominski, A.T. Expression of RCAS1 correlates with urothelial bladder cancer malignancy. Int. J. Mol. Sci. 2015, 16, 3783-3803. [CrossRef]

60. Jozwicki, W.; Windorbska, W.; Brozyna, A.A.; Jochymski, C.; Basta, P.; Sikora, J.; Stasienko, E.; Dutsch-Wicherek, M.; Koper, K.; Wicherek, L. The analysis of receptor-binding cancer antigen expressed on SiSo cells (RCAS1) immunoreactivity within the microenvironment of the ovarian cancer lesion relative to the applied therapeutic strategy. Cell Tissue Res. 2011, 345, 405-414. [CrossRef]

61. Tuckey, R.C.; Li, W.; Zjawiony, J.K.; Zmijewski, M.A.; Nguyen, M.N.; Sweatman, T.; Miller, D.; Slominski, A. Pathways and products for the metabolism of vitamin D3 by cytochrome P450scc. FEBS J. 2008, 275, 2585-2596. [CrossRef]

62. Slominski, A.; Semak, I.; Zjawiony, J.; Wortsman, J.; Li, W.; Szczesniewski, A.; Tuckey, R.C. The cytochrome P450scc system opens an alternate pathway of vitamin D3 metabolism. FEBS J. 2005, 272, 4080-4090. [CrossRef] [PubMed]

63. Li, W.; Chen, J.; Janjetovic, Z.; Kim, T.K.; Sweatman, T.; Lu, Y.; Zjawiony, J.; Tuckey, R.C.; Miller, D.; Slominski, A. Chemical synthesis of 20S-hydroxyvitamin D3, which shows antiproliferative activity. Steroids 2010, 75, 926-935. [CrossRef]

64. Chaiprasongsuk, A.; Janjetovic, Z.; Kim, T.K.; Jarrett, S.G.; D'Orazio, J.A.; Holick, M.F.; Tang, E.K.Y.; Tuckey, R.C.; Panich, U.; Li, W.; et al. Protective effects of novel derivatives of vitamin D3 and lumisterol against UVB-induced damage in human keratinocytes involve activation of Nrf2 and p53 defense mechanisms. Redox Biol. 2019, 24, 101206. [CrossRef] [PubMed]

65. Johnson, S.; Chen, H.; Lo, P.K. In vitro Tumorsphere Formation Assays. Bio Protoc. 2013, 3, e325. [CrossRef] [PubMed]

66. Giaginis, C.; Giagini, A.; Theocharis, S. Receptor-binding cancer antigen expressed on SiSo cells (RCAS1): A novel biomarker in the diagnosis and prognosis of human neoplasia. Histol. Histopathol. 2009, 24, 761-776. [CrossRef] [PubMed]

67. Sonoda, K.; Miyamoto, S.; Yamazaki, A.; Kobayashi, H.; Nakashima, M.; Mekada, E.; Wake, N. Biologic significance of receptor-binding cancer antigen expressed on SiSo cells (RCAS1) as a pivotal regulator of tumor growth through angiogenesis in human uterine cancer. Cancer 2007, 110, 1979-1990. [CrossRef] [PubMed]

68. Miyazaki, T.; Ikeda, K.; Sato, W.; Horie-Inoue, K.; Inoue, S. Extracellular vesicle-mediated EBAG9 transfer from cancer cells to tumor microenvironment promotes immune escape and tumor progression. Oncogenesis 2018, 7, 7. [CrossRef]

69. Slominski, A.; Pisarchik, A.; Johansson, O.; Jing, C.; Semak, I.; Slugocki, G.; Wortsman, J. Tryptophan hydroxylase expression in human skin cells. Biochim. Biophys. Acta 2003, 1639, 80-86. [CrossRef] 
70. Villena-Heinsen, C.; Meyberg, R.; Axt-Fliedner, R.; Reitnauer, K.; Reichrath, J.; Friedrich, M. Immunohistochemical analysis of 1,25-dihydroxyvitamin-D3-receptors, estrogen and progesterone receptors and Ki-67 in ovarian carcinoma. Anticancer Res. 2002, 22, 2261-2267.

71. Friedrich, M.; Rafi, L.; Mitschele, T.; Tilgen, W.; Schmidt, W.; Reichrath, J. Analysis of the vitamin D system in cervical carcinomas, breast cancer and ovarian cancer. Recent Results Cancer Res. 2003, 164, 239-246.

72. Thill, M.; Fischer, D.; Kelling, K.; Hoellen, F.; Dittmer, C.; Hornemann, A.; Salehin, D.; Diedrich, K.; Friedrich, M.; Becker, S. Expression of vitamin D receptor (VDR), cyclooxygenase-2 (COX-2) and 15-hydroxyprostaglandin dehydrogenase (15-PGDH) in benign and malignant ovarian tissue and 25-hydroxycholecalciferol (25(OH2)D3) and prostaglandin E2 (PGE2) serum level in ovarian cancer patients. J. Steroid Biochem. Mol. Biol. 2010, 121, 387-390. [CrossRef] [PubMed]

73. Cordes, T.; Hoellen, F.; Dittmer, C.; Salehin, D.; Kummel, S.; Friedrich, M.; Koster, F.; Becker, S.; Diedrich, K.; Thill, M. Correlation of prostaglandin metabolizing enzymes and serum PGE2 levels with vitamin D receptor and serum 25(OH)2D3 levels in breast and ovarian cancer. Anticancer Res. 2012, 32, 351-357. [PubMed]

74. Pejovic, T.; Joshi, S.; Campbell, S.; Thisted, S.; Xu, F.; Xu, J. Association between vitamin D and ovarian cancer development in BRCA1 mutation carriers. Oncotarget 2020, 11, 4104-4114. [CrossRef]

75. Markiewicz, A.; Brozyna, A.A.; Podgorska, E.; Elas, M.; Urbanska, K.; Jetten, A.M.; Slominski, A.T.; Jozwicki, W.; Orlowska-Heitzman, J.; Dyduch, G.; et al. Vitamin D receptors (VDR), hydroxylases CYP27B1 and CYP24A1 and retinoid-related orphan receptors (ROR) level in human uveal tract and ocular melanoma with different melanization levels. Sci. Rep. 2019, 9, 9142. [CrossRef]

76. Cross, H.S.; Bises, G.; Lechner, D.; Manhardt, T.; Kallay, E. The Vitamin D endocrine system of the gut-its possible role in colorectal cancer prevention. J. Steroid Biochem Mol. Biol. 2005, 97, 121-128. [CrossRef] [PubMed]

77. Menezes, R.J.; Cheney, R.T.; Husain, A.; Tretiakova, M.; Loewen, G.; Johnson, C.S.; Jayaprakash, V.; Moysich, K.B.; Salgia, R.; Reid, M.E. Vitamin D receptor expression in normal, premalignant, and malignant human lung tissue. Cancer Epidemiol. Biomark. Prev. 2008, 17, 1104-1110. [CrossRef] [PubMed]

78. Byun, J.K.; Choi, Y.K.; Kang, Y.N.; Jang, B.K.; Kang, K.J.; Jeon, Y.H.; Lee, H.W.; Jeon, J.H.; Koo, S.H.; Jeong, W.I.; et al. Retinoic acid-related orphan receptor alpha reprograms glucose metabolism in glutamine-deficient hepatoma cells. Hepatology 2015, 61, 953-964. [CrossRef]

79. Oh, T.G.; Wang, S.M.; Acharya, B.R.; Goode, J.M.; Graham, J.D.; Clarke, C.L.; Yap, A.S.; Muscat, G.E.O. The Nuclear Receptor, RORgamma, Regulates Pathways Necessary for Breast Cancer Metastasis. EBioMedicine 2016, 6, 59-72. [CrossRef]

80. Oh, T.G.; Bailey, P.; Dray, E.; Smith, A.G.; Goode, J.; Eriksson, N.; Funder, J.W.; Fuller, P.J.; Simpson, E.R.; Tilley, W.D.; et al. PRMT2 and RORgamma expression are associated with breast cancer survival outcomes. Mol. Endocrinol. 2014, 28, 1166-1185. [CrossRef]

81. Janjetovic, Z.; Brozyna, A.; Tuckey, R.C.; Kim, T.-K.; Nguyen, M.N.; Jozwicki, W.; Pfeffer, S.R.; Pfeffer, L.M.; Slominski, A.T. High basal NF-kB activity in nonpigmented melanoma cells is associated with an enhanced sensitivity to vitamin D3 derivatives. Br. J. Cancer 2011, 105, 1874-1884. [CrossRef]

82. Oak, A.S.W.; Bocheva, G.; Kim, T.K.; Brozyna, A.A.; Janjetovic, Z.; Athar, M.; Tuckey, R.C.; Slominski, A.T. Noncalcemic Vitamin D Hydroxyderivatives Inhibit Human Oral Squamous Cell Carcinoma and Down-regulate Hedgehog and WNT/beta-Catenin Pathways. Anticancer Res. 2020, 40, 2467-2474. [CrossRef] [PubMed]

83. Liu, L.; Hu, Z.; Zhang, H.; Hou, Y.; Zhang, Z.; Zhou, G.; Li, B. Vitamin D postpones the progression of epithelial ovarian cancer induced by 7,12-dimethylbenz [a] anthracene both in vitro and in vivo. OncoTargets Ther. 2016, 9, 2365-2375. [CrossRef] [PubMed]

84. Thill, M.; Woeste, A.; Reichert, K.; Fischer, D.; Rody, A.; Friedrich, M.; Koster, F. Vitamin D inhibits ovarian cancer cell line proliferation in combination with celecoxib and suppresses cyclooxygenase-2 expression. Anticancer Res. 2015, 35, 1197-1203. [PubMed]

85. Zhang, X.; Jiang, F.; Li, P.; Li, C.; Ma, Q.; Nicosia, S.V.; Bai, W. Growth suppression of ovarian cancer xenografts in nude mice by vitamin D analogue EB1089. Clin. Cancer Res. 2005, 11, 323-328. [PubMed]

86. Lungchukiet, P.; Sun, Y.; Kasiappan, R.; Quarni, W.; Nicosia, S.V.; Zhang, X.; Bai, W. Suppression of epithelial ovarian cancer invasion into the omentum by 1alpha,25-dihydroxyvitamin D3 and its receptor. J. Steroid Biochem. Mol. Biol. 2015, 148, 138-147. [CrossRef] [PubMed] 
87. Kasiappan, R.; Shen, Z.; Tse, A.K.; Jinwal, U.; Tang, J.; Lungchukiet, P.; Sun, Y.; Kruk, P.; Nicosia, S.V.; Zhang, X.; et al. 1,25-Dihydroxyvitamin D3 suppresses telomerase expression and human cancer growth through microRNA-498. J. Biol. Chem. 2012, 287, 41297-41309. [CrossRef]

88. Gascoyne, D.M.; Lyne, L.; Spearman, H.; Buffa, F.M.; Soilleux, E.J.; Banham, A.H. Vitamin D Receptor Expression in Plasmablastic Lymphoma and Myeloma Cells Confers Susceptibility to Vitamin D. Endocrinology 2017, 158, 503-515. [CrossRef] [PubMed]

89. Wang, Y.; Solt, L.A.; Kojetin, D.J.; Burris, T.P. Regulation of p53 stability and apoptosis by a ROR agonist. PLOS ONE 2012, 7, e34921. [CrossRef] [PubMed]

Publisher's Note: MDPI stays neutral with regard to jurisdictional claims in published maps and institutional affiliations.

(C) 2020 by the authors. Licensee MDPI, Basel, Switzerland. This article is an open access article distributed under the terms and conditions of the Creative Commons Attribution (CC BY) license (http://creativecommons.org/licenses/by/4.0/). 